\title{
Às voltas com o legado oitocentista: notas sobre a atual historiografia crítica do Direito
}

\section{Romano*}

\author{
Tackling the $19^{\text {th }}$ Century legacy again: notes on current critical histography of Roman Law
}

Rafael Ramis Barceló**

\section{REFERÊNCIA}

RAMIS BARCELÓ, Rafael. Às voltas com o legado oitocentista: notas sobre a atual historiografia crítica do Direito Romano. Revista da Faculdade de Direito da UFRGS, Porto Alegre, n. 45, p. 35-102, abr. 2021. DOI: https://doi.org/10.22456/0104-6594.113641.

\section{RESUMO}

Este artigo tenta explicar o desenvolvimento da historiografia do Direito Romano nos séculos XIX e XX. Defendo que os conceitos e a linguagem de Hegel não foram criticados por Ranke, Savigny e Mommsen, que separaram as suas respectivas áreas de conhecimento (História, Direito Público, Direito Privado). Quando Savigny colocou o sistema de Direito Romano no BGB, os Romanistas tinham duas formas: a) "ad intra", trabalhando nas Faculdades de Direito separadamente das Humanidades (e cooperando com os jusprivatistas); b) "ad extra", com trabalho interdisciplinar com os professores das Faculdades de Humanidades. Resumi estas tendências, revendo a literatura mais recente (2005-2010). Concluo que ambos os caminhos terminam com uma crítica aos conceitos hegelianos e ambos superam a separação do Direito Romano de outras áreas do conhecimento.

\section{PALAVRAS-CHAVE}

Direito Romano. Historiografia. Neopandectismo. Humanismo Jurídico. Antropologia Jurídica.

\begin{abstract}
This paper tries to explain the development of the historiography of Roman Law in 19th and 20th centuries. I claim that the concepts and the language of Hegel were not critically assumed by Ranke, Savigny and Mommsen, which separated their respective areas of knowledge (History, Public Law, Private Law). When Savigny put the system of Roman Law into BGB, Romanists had two ways: a) "ad intra", working at Law School separated from Humanities (and cooperating with Private Law scholars); b) "ad extra", with an interdisciplinary work with scholars of Faculties of Humanities. I summarize these trends reviewing the current bibliography (2005-2010). I conclude that both ways finish with a critique of Hegelian concepts and both exceed the separation of Roman Law from the other areas of knowledge.
\end{abstract}

\section{KEYWORDS}

Roman Law. Historiography. Neopandectism. Legal Humanism. Legal Anthropology.

\footnotetext{
* Texto original em espanhol: RAMIS BARCELÓ, Rafael. A vueltas con el legado decimonónico: notas sobre la actual historiografía crítica del Derecho romano. E-Legal History Review. no 11, 2011, p. 1-52. Tradução para a língua portuguesa por Nathalia Kosinski Rodrigues (Especialista em Direito do Estado pela UFRGS). Revisão da tradução por Alfredo de J. Flores (Professor Permanente do PPGD-UFRGS). Os tradutores agradecem a autorização dada pelo autor e pela revista E-Legal History Review para a presente tradução. Em seu texto original, o autor tece agradecimentos: "Estou em dívida por seus comentários e apoio com os professores Francisco J. Andrés Santos, Alfonso Castro Sáenz, Rosario de Castro Camero, Francisco J. Contreras Peláez, Víctor Méndez Baiges, Gonçal Mayos Solsona, Tomàs de Montagut i Estragués, Antonio Planas Rosselló, José María Royo Arpón e Josep Maria Vilajosana Rubio. A todos eles, meu mais sincero agradecimento".

** Professor de História do Direito e das Instituições da Universitat de les Illes Balears desde 2010. Graduado em Direito, Filosofia, Literatura Comparada, Ciências Políticas e Sociologia. Doutor em Direito pela Universitat Pompeu Fabra.
} 


\section{SUMÁRIO}

1 Introdução. 2 A historiografia a partir do século XIX. 3 A abertura no século XX. 3.1 A investigação "ad intra". 3.1.1 A corrente neopandectista. 3.1.2 A corrente neo-humanista. 3.1.2.1 A aproximação históricofilológica. 3.1.2.2 A aproximação histórico-cultural. 3.1.3 A investigação "ad intra": um rápido balanço. 3.2 A investigação "ad extra". 3.2.1 A corrente histórico-contextualista. 3.2.1.1 Subjetivista. 3.2.1.2 Objetivista. 3.2.2 A corrente antropológico-crítica. 3.2.2.1 A visão foucaultiana. 3.2.3 A corrente da Antropologia jurídica. 3.2.4 A investigação "ad extra": um rápido balanço. 4 Conclusões. Referências.

\section{INTRODUÇÃO}

No presente artigo, pretendo aproximar-me da historiografia crítica do Direito Romano, tomando como pontos de discussão alguns dos livros mais recentemente publicados (2005-2010), alguns dos quais estão escritos ou traduzidos em língua espanhola. A classificação historiográfica que aqui se propõe está longe de ser exaustiva. Tem um caráter meramente orientativo, ainda que seja concebida para compreender alguns pontos-chave referentes às mudanças conceituais e epistemológicas que articularam a historiografia do Direito Romano desde o século XIX até a atualidade ${ }^{1}$.

Depois de examinar sua historiografia no século XX, atentando em particular à sua construção conceitual em paralelo às disciplinas irmãs, tentar-se-á explicar quais são algumas das linhas atuais. Minha intenção é mostrar quais foram as mudanças no método de historicização do Direito Romano e, em particular, as nem sempre fluidas relações entre os juristas romanistas e os historiadores, filósofos e filólogos.

Para tanto, em primeiro lugar, traçarei uma rápida incursão pela historiografia romanística do século XIX, abordando o nascimento do positivismo jurídico, histórico e filosófico, e suas relações com a Escola histórica. Pretendo mostrar qual foi a influência de Hegel no estabelecimento de Roma como cliché categorial e qual foi sua reação contrária durante o século XX, tanto mediante uma metamorfose quanto mediante uma oposição. Essas duas reações são o que considerarei ao longo destas páginas como historiografia crítica frente à tradicional, assentada no século XIX.

A historiografia atual, como se verá, critica o modelo hegeliano e luta para afastar-se de uma categorização absoluta e dogmática de Roma, ainda que difira ao propor diferentes alternativas a esse modelo. Escolhi algumas das obras mais representativas da atualidade - em particular, do último quinquênio - para exemplificar os caminhos metodológicos e para tentar

\footnotetext{
${ }^{1}$ Um rápido resumo dos precedentes pode ser encontrado em: GARCÍA GARRIDO, Manuel Jesús. El Derecho romano y la historiografía jurídica del siglo XIX. Boletín de la Facultad de Derecho de la UNED, n. 14, p. 7592, 1999.
} 
esboçar uma classificação ideológica das tendências da Romanística atual para entender as mudanças na historiografia.

Considero que pode ser eficaz para a exposição do tema - em vista da extensão do presente artigo - apresentar a seguir uma breve sinopse das teses principais que pretendo sustentar. Dessa forma, o leitor poderá conhecer de antemão quais são as linhas principais e não correrá o risco de perder-se no grande emaranhado conceitual e bibliográfico.

A tese principal do meu artigo defende que, para se entender o desenvolvimento da historiografia do Direito Romano no século XX, deve-se buscar suas raízes no século XIX. Em especial, defendo que Hegel é o último autor que busca a unidade do saber em um sistema de pensamento, e sua categorização conceitual é assumida de forma acrítica por historiadores, juristas e filólogos.

Em particular, a linguagem idealista é assumida, assim, por: a) Ranke, que defende um positivismo que se restringe aos dados e à erudição, mas não ataca os conceitos de Hegel, b) Savigny, que tenta proteger o Direito Romano privado ao transformá-lo em um conjunto de conceitos, e c) Mommsen, cujos trabalhos historiográficos só se concentravam no Direito público e na história política. Portanto, ao perseguirem esses três autores o objetivo de “preservar” sua parcela, não impugnam o modelo categorial de Hegel, que define Roma como império pragmático de juristas e de aristocratas, onde o Direito era o privado e o público era a política.

O modelo de "Direito Romano" como conjunto de Direito privado foi favorecido por Savigny até que, em 1900, promulgou-se o BGB. A partir desse momento, os romanistas tinham apenas dois caminhos: por um lado, a) servir como lacaios dos civilistas ou encerrarse na Faculdade de Direito, dedicando-se a questões de interesse duvidoso; por outro, b) tentar promover uma "unidade do saber", colaborando com os professores de Filosofia e de Letras.

A opção a) é a que chamo de "ad intra": juristas romanistas fechados em si mesmos ou, ao menos, colaborando com os jusprivatistas. A opção b) é a que chamo de "ad extra", que abrange o trabalho de juristas romanistas que se abrem à interdisciplinaridade, em um trabalho lado a lado com os professores das faculdades de Filosofia e de Letras.

Tendo em vista os atuais trabalhos, entendo que a Romanística tem de ser crítica com o modelo hegeliano, mas somente pode sê-lo se reconhecer sua dívida com ele e a superar. Tanto o modelo "ad intra" como o "ad extra" configuram - e assim se têm feito claramente nos últimos anos - uma historiografia crítica que seja capaz de superar a herança do século XIX. 
Antes de adentrar à exposição, cabe fazer uma breve referência à visão a partir da qual se enfoca o tema: busquei estudar a historiografia do Direito Romano a partir da história das ideias. Minha formação não é a de um romanista, mas de um historiador do pensamento jurídico, o qual tenta - ainda que seja ousadia - trazer seu modesto ponto de vista externo sobre o vasto panorama romanístico.

\section{A HISTORIOGRAFIA A PARTIR DO SÉCULO XIX}

Na primeira metade do século XIX, esclareceram-se, de forma paralela, entre muitas outras questões acadêmicas, a discussão sobre a necessidade da codificação e o nascimento da historiografia crítica e erudita. Mais além de uma mera coincidência, a conjunção de ambos os vetores significou uma mudança substancial na compreensão no Direito Romano. Com efeito, ele se encontrava sob uma dupla ameaça: de um lado, a iminência da codificação em boa parte da Europa, que apartava definitivamente o Direito Romano como Direito positivo; e, por outro, a possibilidade de que os historiadores aplicassem aos textos jurídicos uma análise exegética e crítica de caráter extrajurídico.

De bom grado, pode-se dizer que, frente à centúria anterior, o século XIX situou-se sob a órbita do positivismo dos dados e das fontes, e que, com ele, consagrou um episódio novo e - até certo ponto - crítico. O positivismo acabou instalando-se como uma reação ao hegelianismo, ainda que - como se verá - assumindo dogmas, em muitos casos acriticamente. A historiografia do Direito Romano - como qualquer outra historiografia do século XIX - não pode ser entendida sem Hegel, que foi o ponto de partida ao qual aderiram ou contra o qual combateram os teóricos posteriores ${ }^{2}$.

Sem o enfrentamento entre Hegel e Savigny ${ }^{3}$, não se poderia entender a impugnação que Ranke fez ao hegelianismo. Os vetores jurídico e histórico pareciam confluir para a oposição ao idealismo hegeliano. O historicismo de Savigny se alinhava contra a codificação

\footnotetext{
${ }^{2}$ Para uma visão panorâmica destas questões, ver: WHITMAN, James Q. The legacy of Roman law in the German romantic era: historical vision and legal change. Princeton: Princeton University Press, 1990.

${ }^{3}$ Sobre esta questão, segue sendo imprescindível: SCHIAVONE, Aldo. Alle origini del diritto borghese: Hegel contro Savigny. Roma; Bari: Laterza, 1984. Também, do mesmo autor: SCHIAVONE, Aldo. Storiografia e critica del diritto: per una 'archeologia' del diritto privato moderno. Bari: De Donato, 1880 - cujo quarto capítulo discuto neste trabalho de forma implícita.
} 
e mostrava seu desacordo com o idealismo da filosofia da história de $\mathrm{Hegel}^{4}$. Ranke, quando se estabeleceu como professor em Berlim, apoiou Savigny contra Hegel, acentuando o aspecto anti-idealista que deveria ter a História ${ }^{5}$.

Ao final, pode-se dizer que Savigny e Ranke - em parte - venceram. O projeto de codificação na Alemanha foi consumado, mas, durante o século XIX, houve tempo suficiente para adaptar o Direito Romano a uma nova dimensão: que passou a funcionar como sistema, e não tanto como fonte. Savigny e seus adeptos conseguiram retardar em quase cem anos a codificação que Hegel reclamava como produto da razão. Com ele salvou - possivelmente de forma pirrônica - o Direito Romano de uma queima quase inevitável.

Certamente, o afã codificador da burguesia era a melodia dos novos tempos, e as Nações europeias adaptaram sua letra àquela melodia. O labor de Savigny foi salvar a letra, que logo se adaptou a esta música tão contagiante que se iniciou na França e foi se expandindo por todo o continente. Savigny, então, garantiu que o Direito Romano se tornasse um sistema, e que, em uma máxima expressão do jusnaturalismo racionalista, ficasse perfeitamente ordenado para sua transferência ao Código ${ }^{6}$. O labor de Savigny foi, mutatis mutandis e superadas todas as distâncias, uma espécie de preparação de um Edito Perpétuo, disposto para que a codificação selasse a máxima expressão do Direito racional, encarnada na perfeição do Direito Romano.

A diferença entre o Edito Perpétuo e a codificação é que aquele coletava toda a tradição romanística para continuar em um mesmo regime, enquanto que a codificação pressupunha - paradoxalmente - a transferência da experiência jurídica de um regime jurídico a outro regime completamente distinto. Em termos estritos, pode-se dizer que Savigny deu continuidade ao significado jurídico-político de um Direito privado quando não existia homogeneidade alguma entre os ordenamentos jurídicos ${ }^{7}$.

\footnotetext{
${ }^{4}$ RÜCKERT, Joachim. Savignys Einflu $\beta$ auf die Jurisprudenz in Deutschland nach 1900. In: MOHNHAUPT, Heinz. Rechtsgeschichte in den beiden deutschen Staaten (1988-1990). Frankfurt am Main: Klostermann, 1991. p. 34-71.

5 BERMEJO BARRERA, José. Carlos; PIEDRAS MONROY, Pedro Andrés. Genealogía de la historia: Ensayos de historia teórica. Madrid: Akal, 1999. p. 80-88.

${ }^{6}$ Ver a sugestiva leitura: CONTRERAS PELÁEZ, Francisco José. Savigny y el historicismo jurídico. Madrid: Tecnos, 2004. O professor Contreras destaca, essencialmente, duas contradições no pensamento de Savigny: o encobrimento do Direito Romano por um pretenso Direito histórico, e a indefinição desse Direito Romano entre o jusnaturalismo (racionalista e abstrato) e o positivismo, no momento em que se prepara para a codificação. Ver, também: ANDRÉS SANTOS, Francisco Javier. El ambiguo historicismo de Savigny. Seminarios complutenses de Derecho romano - Revista Complutense de Derecho Romano y tradición romanística, n. 19, p. 365-381, 2006.

${ }^{7}$ Ver: VILAJOSANA, Josep M. El significado político del Derecho. México: Fontamara, 1997.
} 
Savigny travou a batalha pelo Direito Romano sob as roupagens da Escola histórica do Direito, uma contradição importante que era dificilmente salvável ${ }^{8}$. Com o pretexto de salvaguardar o Direito histórico alemão, dedicou-se totalmente a preservar o Direito Romano, e a convertê-lo em um conjunto abstrato de princípios que, sob o rótulo de Direito histórico, preparavam a positivação do Direito Romano como base do BGB.

De sua parte, Ranke conseguiu impor seu método positivista, baseado na história encadeada a partir das bibliografias dos grandes homens e dos feitos políticos (tratados, batalhas...). A atenção aos dados e ao meramente empírico acabou com a metodologia hegeliana e com a possível história universal baseada em seu pensamento. Unindo-se à obra de Auguste Comte, Ranke conseguiu impor um método que foi compartilhado por quase todos os historiadores até a mudança proposta pela Escola dos Annales?.

Hegel perdeu, sem dúvida, a batalha da universalidade do saber e da encarnação deste em uma história universal baseada no progresso. O século XIX foi a época da emancipação dos diferentes saberes, algo que o positivismo encorajou abertamente. Por um lado, permanecia o Direito Romano, transformado em ciência do Direito e, por outro, a história, que havia passado a ser uma disciplina empírica. Também a filologia e a literatura haviam se separado do tronco comum da filosofia hegeliana, adotando - como fez paradigmaticamente Saint Beuve - o florescente positivismo.

Todas estas disciplinas acataram progressivamente o método positivista. Ganharam, por assim dizer, as primeiras batalhas contra Hegel. Sua vitória - como disse - foi pirrônica, porque a sombra do filósofo pairou sobre as diferentes disciplinas, de forma quase inconsciente. Poderia dizer-se que Hegel reinou depois de morrer, mas o fez de forma indireta. As disciplinas haviam se emancipado e seu método, certamente, havia mudado. Contudo, não o fizeram suas categorias. A proeminência categorial de Hegel durante o século XIX e boa parte do século XX foi um feito incontestável.

No âmbito da história, tal marca pode ser vista claramente, entre outras coisas, na periodização. "Roma" passou a ser um conceito histórico, do mesmo modo que o era, para Hegel, "Oriente" ou "Grécia”. A categoria "Roma” implicava não só a conceitualização como um todo, mas também a admissão de somente uma cronologia e a aceitação de uma série de

\footnotetext{
${ }^{8}$ CONTRERAS PELÁEZ, Francisco José. La idea de espíritu del pueblo en F. C. V. Savigny. Anales de la Cátedra Francisco Suárez, n. 35, p. 161-187, 2001. Ver, também: CONTRERAS PELÁEZ, Francisco José. Savigny y el historicismo jurídico. Madrid: Tecnos, 2004.

${ }^{9}$ BURGUIÈRE, André. La escuela de los Annales: Una historia intelectual. Valencia: Universidad de Valencia, 2009. cap. 1.
} 
tópicos hegelianos associados a ela, entre os que destacavam sua "aristocracia" e seu "pragmatismo".

\begin{abstract}
A antítese tem por primeiro plano o universal, no qual o indivíduo se perde e obtém permissão para ser senhor por si, sob a condição de obedecer ao Estado abstrato. O sujeito abstrato e fixo é, portanto, o segundo termo, que se encontra frente ao universal abstrato. O Direito estrito da personalidade se encontra, então, expressado também nessa antítese. Em Roma, é onde encontramos agora esta livre universalidade, esta liberdade abstrata, que põe o Estado abstrato, a política e o poder acima da individualidade concreta, que fica inteiramente subordinada; e que, por outro lado, cria, frente a essa universalidade, a personalidade - a liberdade do eu em si - que deve distinguir-se da individualidade. A personalidade constitui a determinação fundamental do Direito; surge à existência, principalmente na propriedade; mas é indiferente às determinações concretas do espírito vivo, às quais se refere a individualidade. Estes dois momentos que formam Roma - a universalidade política por si e a liberdade abstrata do indivíduo em si mesmo estão compreendidos, primeiro, na forma da própria interioridade. Essa interioridade, este retrair-se a si mesmo, que vimos tornar-se a perdição do espírito grego, converte-se aqui no terreno sobre o qual brota uma nova fase da história universal. Na consideração do mundo romano, não se trata de uma vida espiritual concreta e rica em si; o concreto nessa universalidade é somente a dominação prosaica prática. Este é o fim que se persegue, com uma dura falta de espírito e de coração, que, ao cabo, só faz prevalecer esta abstração da universalidade. Não encontramos aqui uma vida livre, capaz de desfrutar do teórico, mas uma vida sem vida que se conserva praticamente ${ }^{10}$.
\end{abstract}

Encontra-se no texto acima a idealização do "romano" como conceito, assim como a captação de seu “espírito". Grande parte desta abstração, como noção geral, continuou depois da morte de Hegel - na mente dos eruditos. Dito de forma evidente, se nos dias de hoje perdura, por exemplo, o tópico dos pragmáticos romanos, juristas e engenheiros, frente ao dos gregos, filósofos e artistas, deve-se isso a um desenvolvimento de um cliché categorial que Herder iniciou ${ }^{11}$ e que Hegel solidificou ${ }^{12}$.

No âmbito do Direito, depois da experiência do "ius commune", que amalgamou o Direito justinianeu com o canônico e o feudal, voltou-se a reivindicar a pureza do Direito Romano como "sistema", tomando a obra de Justiniano como um compêndio, em vez de uma antologia de textos de procedência muito díspar. Ao final, sem que a mediação do humanismo jurídico viesse a servir - por último - para remediá-lo, o "Direito Romano", depois do Iluminismo e da sábia intervenção de Savigny, passava a ser "o Direito da razão". Daí que

\footnotetext{
${ }^{10}$ HEGEL, George Wilhelm Friedrich. Lecciones sobre filosofía de la historia universal. Madrid: Alianza, 1974. p. 499-500.

${ }^{11}$ CONTRERAS PELÁEZ, Francisco José. La filosofía de la historia de Johann G. Herder. Sevilla: Universidad de Sevilla, 2004. p. 26.

${ }^{12}$ HEGEL, George Wilhelm Friedrich. Lecciones sobre filosofía de la historia universal. Madrid: Alianza, 1974. p. 532: "El principio romano se presenta, pues, como la fría abstracción del poder y de la violencia, como el puro egoísmo de la voluntad frente a los demás, egoísmo que no tiene en sí ninguna satisfacción ética, sino que toma su contenido únicamente de los intereses particulares".
} 
Fikentscher escreve que "rompe-se em Savigny a referência histórica: a História já realizou sua missão e pode ir embora""13.

Meditando sobre os resultados da Pandectística desde a releitura da Filosofia do Direito de Hegel, pode-se ver até que ponto Savigny teve que trair o ideal historicista - se é que ele mesmo o defendia - para salvar "o futuro" do Direito Romano. Teve que assegurar sua sobrevivência, ainda quando ele já não era uma fonte direta. O preço a pagar foi convertêlo em uma "dogmática" a-histórica, em um sistema racional e ordenado, em um conjunto de princípios logicamente derivados entre $\mathrm{si}^{14}$. Por fim, e depois de muitas mediações, dava-se um cumprimento tardio e metamorfoseado do que Hegel havia proposto em sua Filosofia do Direito.

O reinado indireto de Hegel não só se consumiu na promulgação do BGB; também se deu por causa da emancipação de cada um dos saberes, um fato que impedia, em parte, a interferência da filosofia neles, mas que, por outra, impossibilitava a comunicação das disciplinas entre si. Os novos saberes, independentes já da tutela das Artes e da Filosofia, não variaram os clichés categoriais, e assumiram dogmaticamente as categorias da compilação do passado, adaptadas a um presente que não atacava a construção ontológica dos saberes ${ }^{15}$.

Como é sabido, no Antigo Regime, proliferavam os estudantes que simultaneamente cursavam cursos de Direito, Filosofia e Teologia. Em meados do século XIX, cada disciplina havia se emancipado das demais, e os graduados se especializaram cada vez mais, levantando muros entre as diferentes disciplinas. Quase todas elas, porém, seguiam fiéis às categorias do último sistema de pensamento europeu, de Hegel, entre outras coisas porque, individualmente e desde uma perspectiva concreta, não poderiam mudar as categorias estabelecidas a partir da "totalidade" $"$.

Os muros entre as disciplinas permitiram que o reinado indireto de Hegel se prolongasse amplamente. De fato, a especialização fez, por exemplo, com que os historiadores se dedicassem à história política de Roma; os filólogos, ao estudo dos textos

\footnotetext{
${ }^{13}$ FIKENTSCHER, Wolfgang. La concepción de la Historia y del Sistema de Savigny. Anales de la Cátedra Francisco Suárez, n. 18-19, p. 64, 1978-1979.

${ }^{14}$ BÖCKENFÖRDE, Ernst-Wolfgang. Die Historische Schule und das Problem der Geschichtlichkeit des Rechts. In: BÖCKENFÖRDE, Ernst-Wolfgang. Staat, Gesellschaft, Freiheit: Studien zur Staatstheorie und zum Verfassungsrecht. Frankfurt am Main: Suhrkamp, 1976. p. 20 et seq.

${ }^{15}$ NOIRIEL, Gérard. Sobre la crisis de la historia. Madrid: Cátedra, 1997. p. 54 et seq.

${ }^{16}$ BERMEJO BARRERA, José. Carlos. Introducción a la historia teórica. Tres Cantos: Akal, 2009. p. 194: “En Hegel quedan recogidas las aportaciones de la teología de la Historia y de la Filosofía de la Ilustración con vistas a una posible constitución de un discurso histórico. A partir de él, estos supuestos pasarán a ser asumidos, consciente o inconscientemente por todos los historiadores y, por lo tanto, llegarán a constituir uno de los más perdurables fundamentos del discurso histórico".
} 
latinos; e os estudiosos do Direito Romano (que, a partir daqui, chamarei de romanistas), à história e aos textos de Direito Romano. Hegel, advertindo sobre as sementes destas divisões já em sua época, escreveu:

[a] erudição considerou a história romana a partir de muitos pontos de vista; expôs diversas e divergentes opiniões. Isso acontece, principalmente, na mais antiga história romana, que foi estudada por três classes de eruditos: os historiadores, os filólogos e os juristas. Os historiadores se atêm aos aspectos amplos e consideram a história como tal - de modo que é a partir deles que melhor nos orientamos, pois fazem referência a fatos decisivos. Os filólogos, em contrapartida, dão menos valor às tradições gerais, prendendo-se aos detalhes, os quais podem se combinar de várias maneiras. Essas combinações valem primeiro como hipóteses históricas e, pouco depois, como fatos provados. Em grau não inferior aos filólogos, os juristas pegam o Direito Romano para investigar e mesclar com hipóteses os menores detalhes. O resultado foi declarar formidável, de uma ponta a outra, a mais antiga história romana - de onde essa esfera caiu por completo nas mãos da erudição, que sempre se estende por onde pode. ${ }^{17}$

É curioso que os historiadores pudessem lidar com todo tipo de fontes e de dados, salvo os textos "literários" e os "jurídicos". Deve-se recordar aqui que, para Foucault, o conceito de "literatura" nasce nessa época e não é menos importante recordar como a especialização de cada uma das disciplinas determinou o que era "literatura", "filosofia" ou "Direito"18.

Ao final do século XIX, todas as "ciências do espírito" - para dizer com Dilthey tinham em comum o empenho na compilação das fontes e o tratamento diferenciado de cada uma delas, segundo a disciplina. Os romanistas evitaram que os filólogos e os historiadores pusessem suas mãos sobre o Direito justinianeu, canônico e feudal. Para entender os textos jurídicos era preciso ser jurista.

Em que pese a rejeição formal que Mommsen fez à obra de Hegel, em sua História de Roma se consagraram as ideias historiográficas do filósofo. Ao meu entender, Mommsen que combinava as facetas de político, filólogo, jurista e historiador - tentou elaborar um conjunto de obras que oferecesse uma imagem global ${ }^{19}$. O resultado - ainda sendo deslumbrante atualmente - revela, no mínimo, três amarras: a primeira delas, a incapacidade de superar os esquemas hegelianos (a importância do Estado, a missão teleológica deste...); a

\footnotetext{
${ }^{17}$ HEGEL, George Wilhelm Friedrich. Lecciones sobre filosofía de la historia universal. Madrid: Alianza, 1974. p. 500.

${ }^{18}$ FOUCAULT, Michel. De lenguaje y literatura. Barcelona: Paidós ICB/UAB, 1996. p. 68 et seq.

${ }^{19}$ SCHIAVONE, Aldo. Ius. L'invenzione del diritto in Occidente. Torino: Einaudi, 2005. Há tradução ao espanhol: SCHIAVONE, Aldo. Ius. La invención del Derecho en Occidente. Buenos Aires: Adriana Hidalgo, 2009 - pela qual cito. Schiavone (p. 34) destaca que Mommsen tinha bem separadas suas vocações de jurista, historiador e filólogo.
} 
segunda, a separação entre o Direito e a política, áreas que poderiam permanecer justapostas, mas que não se interpenetravam; e, por último, o caráter político da História, entendida como a dialética que se faz com o poder.

Mommsen é, sem dúvida, o ponto de partida central de todos os estudiosos sobre Roma durante o século XX. Sua vastíssima obra, que supõe uma proteção e uma consolidação das descobertas epigráficas, mantém, ao mesmo tempo, fortes vínculos com a historiografia positivista de Ranke e alicerça os princípios da história universal hegeliana. A História de Roma foi lida a partir da construção nacional alemã, e tinha - para Mommsen - um sentido teleológico. Mais além dos períodos (que Mommsen estabeleceu), a História de Roma representa a fixação da categoria "Roma" como história do poder político, social, cultural e militar.

Seu célebre tratado Direito público romano é uma história das instituições políticas, entendidas como as peças de uma história do poder, de suas manifestações e suas representações. Com ele, Mommsen solidificava uma imagem da historiografia de "Roma" como a história da construção política do poder estatal ${ }^{20}$. Pode-se dizer que em sua obra se diferencia claramente o Direito público do Direito privado. O que era propriamente "Direito Romano privado" não era o âmbito de estudo de Mommsen, mas o Direito público ensejava uma história jurídico-política das administrações ${ }^{21}$. Em todo caso, a "pureza” abstrata do BGB se mantinha quase incólume frente aos estudos históricos de Mommsen.

Pode-se dizer, precisamente, que Mommsen fez um trabalho de "abstração" da história das instituições públicas romanas ${ }^{22}$, fundamentalmente graças à ideia da "lei constitucional romana”. Enquanto político liberal e erudito, esse foi seu principal invento historiográfico, que acabou idealizando - de forma bastante hegeliana - a evolução das instituições em Roma como se, ao longo de doze séculos, tivesse sido forjado em Roma uma espécie de constituição de caráter popular ${ }^{23}$. Este "projeto constitucional” estava à margem do estudo do cidadão e de

\footnotetext{
${ }^{20}$ Ver: LÓPEZ BARJA DE QUIROGA, Pedro Manuel. Los partidos políticos en la obra de Mommsen. In: MARTÍNEZ-PINNA, Jorge (coord.). En el centenario de Theodor Mommsen (1817-1903): homenaje desde la Universidad española. Málaga: Universidad de Málaga, 2005. p. 207-218.

${ }^{21}$ BURGUIÈRE, André. Diccionario de ciencias históricas. Madrid: Akal, 1991 - ver a voz "Derecho", e em especial a p. 197.

${ }^{22}$ Ver: MALAVÉ OSUNA, Belén. Mommsen y la ciencia del Derecho público. In: MARTÍNEZ-PINNA, Jorge (coord.). En el centenario de Theodor Mommsen (1817-1903): homenaje desde la Universidad española. Málaga: Universidad de Málaga, 2005. p. 171-178.

${ }^{23}$ As ressalvas à construção abstrata de Mommsen podem ser vistas em: KUNKEL, Wolfgang. Historia del Derecho romano. Barcelona: Ariel, 2003. p. 201 et seq.
} 
seus Direitos, um âmbito que ficava fora da história, e que, em qualquer caso, era matéria própria dos juristas.

As diferenças entre os juristas juspublicistas e os historiadores da política e do Direito público podem ser exemplificada perfeitamente através do estudo do Direito penal romano, comparando a obra de Mommsen ${ }^{24}$ com a de Contardo Ferrini ${ }^{25}$, ambas surgidas em 1899. Se o erudito alemão concebia o Direito penal como uma parte mais de sua história geral de Roma, Ferrini entendeu a história do Direito penal romano desde o ponto de vista estritamente jurídico, dogmático e técnico ${ }^{26}$. Trata-se do muro de contenção que selava as diferenças entre o labor dos juristas e dos historiadores que, como se verá a seguir, marcou o devir do século XX.

\section{A ABERTURA AO SÉCULO XX}

Foi dito até aqui que a história (política) sobre Roma e o Direito Romano (civil) não confluíram durante o século XIX. Nas páginas seguintes, será visto que tampouco o fizeram durante boa parte do século XX, salvo nos poucos casos em que os romanistas se dedicaram ao estudo do Direito público e das instituições, uma área que compartilhavam - não de bom grado - com juristas e historiadores.

O "Direito Romano abstrato" de Savigny foi depositado no BGB e, com isso, os romanistas ganharam quase um século. Contudo, uma vez que o Direito Romano deixava de ser fonte direta, os romanistas se viram na circunstância de justificar seu trabalho. Muitos continuaram explicando o Direito Romano mumificado como conjunto de princípios, pois era a construção abstrata que precedia o Código Civil. Os romanistas poderiam explicar aos civilistas quais eram os problemas do novo Código e, se existissem lacunas ou antinomias, poderiam solvê-las graças ao estudo do Direito Romano.

Puchta levou às últimas consequências a noção de Savigny de "sistema jurídico" e o valor da jurisprudência na interpretação do Direito: com isso, pôs a primeira pedra na chamada "jurisprudência de conceitos", à qual se opunha Ihering com a "jurisprudência de interesses”. A obra de Ihering supôs uma quebra do cientificismo pandectístico e um giro ao

\footnotetext{
${ }^{24}$ MOMMSEN, Theodor. Römisches Strafrecht. Leipzig: Duncker \& Humblot, 1899.

${ }^{25}$ FERRINI, Contardo. Diritto penale romano. Teorie generali. Milano: Hoepli, 1899.

${ }^{26}$ Sobre esta questão, podem ser vistos os comentários de: SANTALUCIA, Bernardo. Altri studi di diritto penale romano. Padova: CEDAM, 2009. p. 454-456.
} 
naturalismo jurídico. Sua obra, de caráter voluntarista, reclamava a força como criação do Direito. Quase todos os romanistas se alinharam à Escola da jurisprudência dos conceitos, e a obra de Ihering se transformou em sociologia jurídica a partir da proposta de Philipp Heck e outros seguidores $^{27}$.

O trabalho de muitos dos romanistas alemães a partir de então, como já ocorria em boa parte da Europa, foi o de obrigar a memorizar a construção romanística do século XIX e, em alguns casos, inclusive explicar uns "fundamentos históricos" do Direito civil a seus alunos. Ao mesmo tempo, permaneciam na retaguarda, caso aparecessem problemas na interpretação do Código. Os outrora todo-poderosos professores de Direito Romano, passaram à "reserva ativa", com grande temor de ser transferidos a uma mera "reserva passiva".

À medida que os problemas exegéticos foram decaindo, os romanistas mais afiados começaram a examinar interpolações e outros problemas de transmissão textual, buscando fragmentos antigos de autenticidade desigual e se recriando na exegese erudita. Os demais se dedicaram simplesmente à nobre tarefa da dignificação e da legitimação dos estudos de Direito, e a incutir uma base rítmica, para que os civilistas desenvolvessem sobre ela sua nova melodia.

Koschaker se deu conta de que, à medida que transcorriam os anos, os romanistas teriam maiores problemas para justificar as suas disciplinas e, o que é pior, para que se legitimassem para si mesmos. Enquanto a história de Roma nas faculdades de Filosofia e de Letras atravessava um período de certo esplendor, o Direito Romano nas Faculdades de Direito se encontrava encurralado, convertido no lacaio que abria a porta para o resplandecente Direito civil.

O Direito civil, em todas as épocas da civilização romana, não esteve separado do Direito mercantil. Foi a experiência oitocentista que separou ambas as esferas no Direito Romano - seguindo a tradição jurídica europeia - e fez com que o estudo mercantil fosse completamente postergado, e cuja recuperação viria da parte de antropólogos e historiadores, tal como se poderá ver a seguir.

Assim, então, os romanistas tinham basicamente dois caminhos: um, o de avançar arrastando o peso histórico e dogmático da disciplina, e outro, o de continuar a investigação com os professores da Faculdade de Filosofia e Letras, em uma colaboração lado a lado. Ao meu entender, estes foram, na sequência, os dois conjuntos de correntes em que seguiu a

${ }^{27}$ Vê-se um resumo desta questão em: CASINOS MORA, Francisco Javier. Nueve siglos de romanismo jurídico. Rivista di Diritto Romano, v. II, p. 351-399, 2002. 
Romanística. O primeiro dos conjuntos pode ser chamado de "ad intra", ou seja, no qual os romanistas, de forma unilateral, foram transformando o âmbito de estudo de seu próprio legado oitocentista; o segundo, denominarei - por simetria - "ad extra", isto é, um conjunto de correntes que os romanistas cultivam em colaboração com filósofos, filólogos, historiadores, antropólogos etc ${ }^{28}$.

Meu interesse está em mostrar que tanto um caminho quanto o outro - ainda que de diferentes maneiras e por distintas proporções - empreenderam um trabalho crítico frente ao Direito Romano oitocentista e, sobretudo, contra a obra de Hegel.

Nas seções seguintes, tentarei situar as obras dos romanistas europeus nestas categorias. Em cada uma das seções, depois de comentar a obra dos mestres europeus, farei referência, também, aos trabalhos dos romanistas espanhóis, que seguem, fundamentalmente, as diversas linhas de investigação cultivadas na Europa.

\subsection{A INVESTIGAÇÃO " $A D$ INTRA"}

Durante o século XX, os romanistas elegeram majoritariamente a opção interna, que, como se pode perceber, tinha que carregar a pesada herança do século XIX e, por extensão, a dos séculos precedentes. A cisão dos romanistas ocorria entre os que se orientavam por seguir Savigny, e os que consideravam que o estudo do Direito Romano como sistema já não tinha vigência, de modo que deveriam regressar à época do humanismo jurídico para estudar as obras a partir de uma visão filológica. Por outro lado, poucos romanistas seguiram Ihering de forma direta, embora o naturalismo de Bonfante pudesse vincular-se com muitas de suas ideias.

Os primeiros, seguidores da concepção sistemática, chamarei aqui, seguindo uma denominação que se consolidou, de neopandectistas. Os segundos chamarei de neohumanistas, pois pretendem vincular-se com a tradição do século XVI e com as vias de crítica textual abertas pela escola do "mos gallicus".

\footnotetext{
${ }^{28}$ Uma visão das atuais correntes da romanística a partir das diferentes temáticas pode ser vista em: CASTRO SÁENZ, Alfonso. Panorámica romanística, una aproximación a las corrientes recientes de la investigación. Crónica jurídica hispalense - Revista de la Facultad de Derecho, n. 7, p. 349-411, 2009.
} 


\subsubsection{A corrente neopandectista}

Os sucessores dos grandes mestres da Pandectística, como Puchta e Windscheid, apesar da promulgação do BGB, não quiseram deixar de lado a construção abstrata dos princípios de Direito Romano que haviam dado lugar ao Código Civil. Certamente, essa construção deixava de ser Direito vigente, mas - segundo os membros desta escola - poderia contribuir com soluções aos problemas jurídicos existentes.

Todavia, cada vez mais, a jurisprudência ia preenchendo as diferentes lacunas, e o trabalho dos romanistas permanecia em um segundo plano. Seu labor como jurisprudentes consultivos estava em decadência, de modo que deveriam renovar profundamente seu método para se legitimarem. As soluções que pareciam vislumbrar-se eram três: uma volta ao passado, uma elaboração casuística, ou então uma configuração da dogmática jurídica por meio do método comparativo.

A primeira foi defendida, como já foi dito, por Koschaker ${ }^{29}$. Este autor considerava que, apesar da codificação e da existência de um Direito nacional novo, o Direito Romano seguia vivendo nele. Em outros termos, a codificação não pressupunha ruptura nem historiográfica nem material entre o Direito Romano e o Direito vigente. Precisamente, graças à contribuição de Savigny, o Direito alemão e, em boa medida, muitos dos outros Direitos europeus, encontravam-se elaborados sob os critérios do Direito Romano.

Portanto, para dizê-lo de uma forma um pouco metafórica, o espírito do Direito Romano permanecia nos códigos. Já não se encontrava da mesma maneira que antes, mas os conceitos eram ainda romanísticos: todos podiam ser encontrados nas fontes e na tradição anterior. Portanto, ao fim e ao cabo, a codificação não havia significado uma cisão fundamental na história do Direito, mas, em vez disso, um passo a mais, em que o Direito Romano continuava vivo.

Neste sentido, Koschaker reclamava uma "volta a Savigny", ou seja, reivindicava a presença do "Direito Romano atual" 30 . Tratava-se de uma forma de recuperar o perdido, ainda que pagando um considerável preço. Resultava claro que o Direito Romano não continuava vivo, mas que se havia acabado com ele para criar outro tipo de Direito. Koschaker,

\footnotetext{
${ }^{29}$ KOSCHAKER, Paul. Europa und das römische Recht. München: Biederstein, 1947. Há tradução ao espanhol de José Santa Cruz Teijeiro: KOSCHAKER, Paul. Europa y el Derecho romano. Madrid: Editorial Revista de Derecho Privado, 1955.

${ }^{30}$ KOSCHAKER, Paul. Europa y el Derecho romano. Madrid: Editorial Revista de Derecho Privado, 1955. p. 346.
} 
entretanto, considerou que só havia tido uma pequena metamorfose, assim como havia ocorrido com a compilação justinianeia ou na prática do "ius commune". Apesar dos problemas e as dificuldades para sua existência, para eles, o Direito Romano estava vivo.

Tratava-se, portanto, de construir uma dogmática do Direito Romano que fosse a "ciência" do Direito Romano. Frente ao Direito civil codificado, a dogmática do Direito Romano poderia reconduzir as diferentes instituições até as suas fontes primitivas, fazendo com que seguissem os caminhos retos e impulsionando uma "ortodoxia" jusprivatista.

A segunda via era menos ambiciosa, mas muito pragmática. Diferentemente do que defendia Koschaker, os partidários do casuísmo romano reconheceram - e seguem reconhecendo - que já não se tratava de um Direito vigente. O Direito Romano, da mesma forma que Savigny, morreu com a promulgação dos Códigos, e não se deve desenterrá-lo. Bastava que o Direito Romano, como construção dogmática, servisse para a aprendizagem do jurista.

A via da casuística romana dependia, certamente, da construção doutrinária prévia do Direito Romano. Tratava-se, portanto, de um trabalho que exigia uma sistemática jurídica prévia que, em última instância, repousava na Pandectística. Contudo, os autores que a cultivavam e a cultivam não creem que o Direito Romano que eles estudam siga sendo Direito vigente, mas uma construção acabada, de caráter histórico, que serve aos alunos para sua formação num Direito que tem um princípio e um fim cronologicamente estabelecidos.

Pode-se dizer que o iniciador desta metodologia foi Emilio Betti ${ }^{31}$, que, de uma forma muito perspicaz, conseguiu tomar partido do Direito Romano, às custas de renunciar a seu caráter vigente. A partir dessa ideia, os estudantes tinham que se exercitar na resolução de casos de Direito Romano, como uma preparação para solucionar questões análogas do Direito positivo. Entretanto, a obra de Betti é tão fecunda que não pode ser reduzida apenas a esta primeira observação, já que - como se verá depois - ele é um autor fundamental para entender o problema da hermenêutica na história do Direito Romano.

A terceira via também tomou o Direito Romano como um meio, mas, neste caso, para o estudo do Direito comparado privado, tanto antigo como moderno. Em geral, o Direito Romano foi entendido como o tronco a partir do qual poderiam ser estudadas as questões mais complexas do Direito privado europeu e como um elemento imprescindível para construir as bases de um Direito universal.

\footnotetext{
${ }^{31}$ BETTI, Emilio. Esercitazione romanistiche su casi pratici: I, Anormalità del negozio giuridico. Padova:
} CEDAM, 1930. 
Esta via foi iniciada por Ludwig Mitteis ${ }^{32}$, e continuada por Wenger ${ }^{33}$. Sua ideia era a de transladar o estudo comparativo moderno ao estudo das instituições romanas. Tal ideia, como depois se verá, estava relacionada ao estudo mais amplo dos Direitos da Antiguidade. Entretanto, seu interesse não era, em absoluto, interdisciplinar, pois não perseguia uma ideia antropológica, mas queria preencher as lacunas do Direito Romano em comparação aos demais direitos. Não é necessário dizer que este método não prosperou metodológica nem historiograficamente.

Na Espanha, graças à centralidade da figura do professor Álvaro D’Ors, o romanista espanhol mais famoso do século XX, todas as linhas desta visão neopandectista, que exalta a dogmática romanística, foram cultivadas em maior ou menor grau ${ }^{34}$. Deve-se enfatizar, da mesma forma, que a linha da casuística, no decorrer das décadas, acabou dando muitos frutos, mas - obviamente - não se traduziu em resultados historiográficos. Por isso, não tratarei dela aqui.

Em contrapartida, a via da dogmática gerou na Europa algumas obras historiográficas de grande renome. Entre elas, cabe destacar a de Fritz Schultz ${ }^{35}$. Este autor alemão, de origem polonesa e judaica, acabou fazendo uma grande síntese do Direito Romano e se consagrou na reconstrução de uma jurisprudência na qual os perfis biográficos e históricos fossem totalmente eliminados.

Schultz conseguiu elaborar uma história do Direito e um manual de síntese (Classical Roman Law) que estabeleceu as bases metodológicas para o estudo de muitas gerações posteriores. A metodologia historiográfica de Schultz se baseava, paradoxalmente, na negação das etapas históricas e na idealização e abstração ${ }^{36}$. Sua History of Roman Legal Science mostrou a evolução conceitual jurídica sem que os juristas interviessem nela. Tratava-se de

\footnotetext{
${ }^{32}$ MITTEIS, Ludwig. Reichsrecht und Volksrecht in den östlichen Provinzen des römischen Kaiserreichs. Leipzig: B. G. Teubner, 1891; MITTEIS, Ludwig. Römisches Privatrecht bis auf die Zeit Diokletians. Leipzig: Duncker \& Humblot, 1908; MITTEIS, Ludwig. Die Lehre von der Stellvertretung nach römischem Recht mit Berücksichtigung des österreichischen Rechts. Wien: Alfred Hölder, 1885.

${ }^{33}$ WENGER, Leopold. Römische und antike Rechtsgeschichte. Graz: Leuschner \& Lubensky's UniversitätsBuchhandlung, 1905; e WENGER, Leopold. Der heutige Stand der römischen Rechtswissenschaft. München: Beck, 1927.

${ }^{34}$ D’ORS, Álvaro. Sobre el valor formativo del Derecho romano. In: D’ORS, Álvaro. Papeles del oficio universitario. Madrid: Rialp, 1961. p. 164 et seq.

${ }^{35}$ SCHULTZ, Fritz. History of Roman Legal Science. Oxford: Clarendon Press, 1946; SCHULTZ, Fritz. Classical Roman Law. Oxford: Clarendon Press, 1951; e SCHULTZ, Fritz. Geschichte der römischen Rechtswissenschaft. Weimar: Böhlaus, 1961.

${ }^{36}$ Neste sentido, por exemplo, o hegelianismo estatalista e idealista de Schultz, como se pode ver: SCHULTZ, Fritz. Principios del Derecho Romano. Madrid: Universidad Complutense, 1990. p. 130 et seq.
} 
uma história do Direito Romano na qual só importavam os conceitos, e representa uma das obras mais acabadas de inspiração dogmática ${ }^{37}$.

Schultz era um firme partidário da dogmática jurídica, que toma - de forma bastante hegeliana - o "Direito Romano" como conceito. Poucos autores seguem a cultivando de maneira tão anti-histórica e acrítica. Por exemplo, no México, o professor Guillermo Floris Margadant ${ }^{38}$ seguiu sua perspectiva a-histórica, mas com algumas modificações.

$\mathrm{Na}$ Espanha, autores como Sainz-Ezquerra ou Fuenteseca ${ }^{39}$ reclamaram uma historicização do método dogmático. Por isso, em seus trabalhos atuais, apontam para uma "história dos conceitos jurídicos": neles, pretendem mostrar a evolução de cada um dos conceitos até os dias de hoje. Isso permite, por um lado, conhecer quais são os conceitos jurídicos romanos que se aplicam na atualidade, e tudo isso em benefício dos civilistas, que agradecem o argumento histórico que os romanistas lhes proporcionam.

No mundo hispânico, José María Sainz-Ezquerra, ${ }^{40}$ Alejandro Guzmán Brito ${ }^{41}$, Javier Paricio $^{42}$ e Alfredo Calonge Matellanes ${ }^{43}$ são exemplos de professores de orientação muito diferente, que, de uma forma crítica quanto à dogmática, souberam traçar uma história conceitual do Direito Romano, reconhecendo as mudanças na Romanística e distinguindo a

\footnotetext{
${ }^{37}$ Uma visão crítica da obra de Schultz pode ser encontrada em: SCHIAVONE, Aldo. Ius. La invención del Derecho en Occidente. Buenos Aires: Adriana Hidalgo, 2009. p. 51-55.

${ }^{38}$ MARGADANT, Guillermo F. Panorama de la historia universal del Derecho: La segunda vida del Derecho romano. México: Porrúa, 1986. [reelaboração parcial de: MARGADANT, Guillermo F. Introducción a la Historia Universal del Derecho. Tomo I. Xalapa: Universidad Veracruzana, 1974].

${ }^{39}$ FUENTESECA DÍAZ, Pablo. Observaciones sobre el futuro del Derecho romano en España. In: Estudios en homenaje al Profesor Francisco Hernández-Tejero. v. II. Madrid: Universidad Complutense, 1994. p. 205-219.

${ }^{40}$ SAINZ-EZQUERRA, José María. Apuntes actuales sobre metodología romanística clásica. Anales de la Facultad de Derecho de la Universidad de La Laguna, n. 9, p. 36-38, 1981-1982 - aqui advogava por uma dogmática romana, mas não neorromanística. Com isso, este professor mostrava seu respaldo à dogmática, sempre que se construísse sobre as fontes diretas.

${ }^{41}$ Alejandro Guzmán Brito mostrou a importância da dogmática do Direito Romano para a codificação civilística chilena, embora tenha distinguido o Direito Romano clássico e o Direito positivo chileno. Ver, por exemplo: GUZMÁN BRITO, Alejandro. La codificación civil en Iberoamérica. Siglos XIX y XX. Santiago de Chile: Editorial Jurídica de Chile, 2000; GUZMÁN BRITO, A. Las cosas incorporales en la doctrina y el Derecho positivo. Santiago: Editorial Jurídica de Chile, 1995; GUZMÁN BRITO, A. Historia de la interpretación de las normas en el Derecho romano. Santiago: Instituto Juan de Solórzano y Pereira, 2000; GUZMÁN BRITO, A. La fijación del Derecho. Contribución al estudio de su concepto y de sus clases y condiciones. Valparaíso: Ediciones Universitarias de Valparaíso, 1977; e GUZMÁN BRITO, A. Ratio scripta. Frankfurt am Main: Vitorio Klostermann, 1981.

42 Javier Paricio, em sua multifacetada trajetória, muito mais italianista que germanista, escreveu - no entanto sobre a formação do conceito de contrato na tradição jurídica ocidental. Ver seu recente trabalho: PARICIO, Javier. Contrato: Formación de un concepto. Cizur Menor: Thompson-Civitas, 2008.

${ }^{43}$ Alfredo Calonge mostrou a transmissão histórica dos conceitos romanos em várias obras muito refinadas metodologicamente. Ver, por exemplo: CALONGE, Alfredo. La compraventa civil de cosa futura (desde Roma a la doctrina europea actual). Salamanca: Núñez, 1963.
} 
história do Direito Romano da exegese dos conceitos dogmáticos no Direito positivo e vigente.

A obra destes autores está indiretamente enriquecida com o debate da chamada "história conceitual" de Koselleck e Gadamer, que ajuda a modificar a "jurisprudência de conceitos" para transformá-la em uma "história dos conceitos jurídicos" ${ }^{44}$. Esta metodologia, longe de ficar em uma pura dogmática pandectista, tenta estudar o decurso histórico de cada um dos conceitos do Direito Romano, sem confundi-lo com o Direito vigente.

Por isso, os partidários da historicização dos conceitos acabaram relativizando o peso da dogmática, pois, ao examinar cada uma das instituições como conceito histórico, veem-se as mutações conceituais - filosóficas e filológicas - do Direito. Uma segunda contribuição, talvez menos crítica, mas também útil, foi a de mostrar a historicidade de cada um dos elementos do Direito vigente. Esta colaboração costuma beneficiar muito aos civilistas, que saem enriquecidos com o contato com a história dos conceitos jurídicos.

A terceira via (de Mitteis e Wenger) sofreu uma importante transformação nos últimos anos. Se eles - dizendo de forma resumida - tentavam aplicar o método comparativo do Direito moderno e contemporâneo ao estudo do Direito Romano, os autores atuais tentam casar o Direito Romano da Pandectística com o Direito comparado atual. Tudo isso se produziu graças a dois fatores: o estudo comparado da história dos Direitos privados europeus, e a criação da Comunidade Econômica Europeia, que se transformou em uma união não só econômica, mas também jurídica.

O estudo da história da ciência do Direito privado na Europa começou a ser estudada graças à fundamental obra do romanista Franz Wieacker ${ }^{45}$. Precisamente, nessa época firmouse o Tratado de Roma, que, devido às sucessivas ampliações, foi adquirindo um caráter mais jurídico, e propiciou, direta ou indiretamente, a unificação dos Direitos privados, fundamentalmente o Direito mercantil. Da mesma forma, a obra do professor Helmut Coing ${ }^{46}$ representou um importante incentivo a esta via. Este último autor, muito vinculado às origens

\footnotetext{
${ }^{44}$ A história conceitual (Begriffsgeschichte) é um campo interdisciplinar de trabalho de historiadores, filósofos e filólogos, no qual tentam estudar a mudança semântica das palavras por meio da história. Surge como uma reação ao positivismo. Talvez a obra mais emblemática desta corrente seja: KOSELLECK, Reinhart (ed.). Historische Semantik und Begriffsgeschichte. Stuttgart: Klett-Cotta, 1979.

${ }^{45}$ WIEACKER, Franz. Privatrechtsgeschichte der Neuzeit unter besonderer Berücksichtigung der deutschen Entwicklung. Göttingen: Vandenhoeck \& Ruprecht, 1967. Há uma notável tradução ao inglês de T. Weir: WIEACKER, Franz. A History of Private Law in Europe, With Particular Reference to Germany. Oxford: Clarendon Press, 1995 - com um prólogo de R. Zimmermann.

${ }^{46}$ COING, Helmut. Europäisches Privatrecht 1500-1800. München: C. H. Beck, 1985; e COING, Helmut. Europäisches Privatrecht, 1800-1914. München: C. H. Beck, 1989. Em espanhol: COING, Helmut. Historia del Derecho privado europeo. Madrid: Fundación Cultural del Notariado, 1996.
} 
do Max-Planck-Institut für Europäische Rechtsgeschichte (MPIER) de Frankfurt am Main, elaborou, também, uma obra histórica e jusfilosófica de grande relevância, mas com pouca incidência na Romanística crítica.

Por conseguinte, o Direito Romano fornecia as fontes necessárias para elaborar uma sistemática que permitia estudar de forma comparada as soluções de davam os diferentes ordenamentos jurídicos às diversas instituições de Direito privado. Assim, o Direito Romano seria a fonte primordial do Direito privado europeu e internacional, e seu estudo dogmático serviria para estabelecer um método concreto de soluções comuns ante o estudo do Direito positivo e de sua sistematização ${ }^{47}$.

Um dos trabalhos mais recentes nessa direção é o do professor Gábor Hamza ${ }^{48}$, que tenta traçar a história da formação dos Direitos privados na Europa por meio de um estudo histórico das raízes romanísticas do Direito europeu e sua metamorfose nos atuais países da Europa. Hamza elabora um imponente mosaico da evolução dos Direitos civis europeus e sua influência nas outras tradições civilistas (asiáticas, americanas e africanas).

De qualquer forma, os internacionalistas quiseram limitar - a partir das origens de sua disciplina - a presença dos romanistas no Direito comparado. Em contrapartida, foram os romanistas que, com maior afinco, quiseram adaptar o sistema pandectista ao Direito privado comparado e, em parte, ao atual Direito comunitário. Desse modo, seu labor permitia sugerir, a partir da dogmática jurídica, quais eram as soluções mais convenientes. E não somente isso: os romanistas, com isso, pretendiam unificar novamente o Direito internacional privado a partir da dogmática romanística, de forma que, apesar das mutações, o Direito Romano continuasse vigente.

Atualmente, quem encabeça esta via é o professor Reinhard Zimmermann. Em suas obras, destaca, por um lado, a importância do estudo conjunto da dogmática e da civilística, de modo que sua continuidade fica acima de qualquer dúvida ${ }^{49}$; por outro, ressalta que a dogmática romanística é a base da construção de um Direito privado europeu.

\footnotetext{
${ }^{47}$ GORDLEY, James; JIANG; Hao; MEHREN, Arthur Taylor von. An Introduction to the Comparative Study of Private Law. Cambridge: Cambridge University Press, 2006.

48 HAMZA, Gábor. Entstehung und Entwicklung der modernen Privatrechtsordnungen und die römischrechtliche Tradition. Budapest: Eötvös Universitätsverlag, 2009.

${ }^{49} \mathrm{O}$ escrito programático de R. Zimmermann é: ZIMMERMANN, R. Savignys Vermächtnis: Rechtsgeschichte, Rechtsvergleichung und die Begründung einer Europäischen Rechtswissenschaft. Tübingen: Juristische Blätter, 1998. Outras obras na mesma direção: ZIMMERMANN, R. The Law of Obligations: Roman Foundations of the Civilian Tradition. Cape Town: Juta \& Co., 1990; ZIMMERMANN, R. Roman Law, Contemporary Law, European Law: The Civilian Tradition Today. Oxford: Oxford University Press, 2001; e ZIMMERMANN, R. Handwörterbuch des Europäischen Privatrechts. v. 1-2. Tübingen: Mohr Siebeck, 2009.
} 
Zimmermann, em colaboração com outros professores, como Rolf Knutel e Jens-Peter Meincke, mostra a vinculação entre o Direito Romano e o atual, de modo que a codificação não implicou nenhuma cisão entre ambos os ordenamentos jurídicos. Zimmermann solidificou o empenho de Mitteis, que não contava com o pretexto da unificação dos Direitos privados da Europa, e relacionou, assim, com as propostas de Koschaker e Savigny.

O programa de Zimmermann pode ser examinado no trabalho "Europa und das römische Rechts", recentemente traduzido ao espanhol ${ }^{50}$. Nele, pode-se ver a solidez das abordagens comparatistas, pagando, não obstante, o preço de homogeneizar a Pandectística e a civilística. A contribuição historiográfica mais destacada deste autor é o interesse no Direito histórico comparado. Para ele, o Direito Romano segue vivo e o faz no marco da história. A codificação não foi mais que uma metamorfose formal que não pode parar o conteúdo romanístico do Direito europeu ${ }^{51}$.

Zimmermann, inclusive, dá um passo a mais: crê que o Direito Romano tem futuro porque é estudado nos países de tradição consuetudinária, algo que mostra sua fecundidade atual. O Direito Romano segue vivo porque continua sendo invocado, segue sendo o conteúdo material do Direito europeu e permanece como a seiva que nutre os estudos jurídicos ${ }^{52}$. Contudo, Zimmermann não é muito partidário do Direito privado comunitário (“Gemeinschaftsprivatrecht"), mas de um Direito privado europeu que resulte unificador com base em uma dogmática; daí o papel diretor que deve ostentar a ciência jurídica (ao modo da Pandectística alemã do século XIX, anterior ao BGB).

$\mathrm{Na}$ Espanha, esta via foi mais apreciada pelos jusprivatistas que pelos próprios romanistas, embora seja certo que alguns mostraram seu acordo com a abordagem de Zimmermann. Professores como Carlos Sánchez del Río - em sua época - já mostraram seu

\footnotetext{
${ }^{50}$ ZIMMERMANN, Reinhard. Europa y el Derecho romano. Estudio introductorio y traducción de I. Cremades Ugarte. Madrid: Marcial Pons, 2009. Ao espanhol foi recentemente traduzido, também: ZIMMERMANN, R. Derecho romano, Derecho contemporáneo, Derecho europeo: La tradición del Derecho civil en la actualidad. Bogotá: Universidad Externado de Colombia, 2010.

${ }^{51}$ ZIMMERMANN, Reinhard. Europa y el Derecho romano. Estudio introductorio y traducción de I. Cremades Ugarte. Madrid: Marcial Pons, 2009. p. 48: "Tenemos así lo que corresponde hacer al Derecho romano para un cambio de perspectiva: junto a lo puramente histórico debe proceder de nuevo a una decidida observación del Derecho moderno, a esa que precisamente posibilita en general una profunda comprensión del mismo, pone de manifiesto las particularidades del desarrollo en comparación con otros ordenamientos jurídicos europeos y hace con esto posible que de nuevo pueda trascenderse el limitado horizonte de una jurisprudencia nacional".

${ }^{52}$ A posição de Zimmermann teve grandes críticos. Nos trabalhos mais recentes, podem ser vistas as críticas de: CARONI, Pio. La soledad del historiador del Derecho. Apuntes sobre la conveniencia de una disciplina diferente. Madrid: Universidad Carlos III de Madrid, 2010. Outros enfoques com um denominador comum podem ser vistos nos trabalhos compilados por: CARONI, Pio; DILCHER, Gerhard (ed.). Norm und Tradition. Köln; Weimar; Wien: Böhlau, 1998.
} 
respaldo à construção de uma "ciência jurídica" europeia, tomando como base o Direito Romano. Hodiernamente, autores como Federico Fernández de Buján e María Isabel Núñez Paz seguem reclamando a continuidade do Direito Romano no Direito europeu atual por meio de seus trabalhos de Direito privado histórico ${ }^{53}$. Em particular, o professor Fernández de Buján, entre muitas outras coisas, reivindicou o papel do Direito Romano na construção de um thesaurus jurídico europeu e na formação de um Direito europeu dos contratos ${ }^{54}$.

Na Itália, G. Luchetti e A. Pretrucchi coordenaram uma obra destinada a traçar os fundamentos do Direito contratual na União Europeia sobre bases romanísticas ${ }^{55}$. Outros professores italianos, como P. Catalano ${ }^{56}$ e S. Schipani ${ }^{57}$, seguem nesta linha neopandectista, ainda que de forma muito sui generis, tentando explicar a evolução do Direito Romano e sua vigência atual em grandes áreas como a América Latina. Os professores L. Garofalo e C. A. Cannata, aos quais irei me referir depois, também compartilham parcialmente desta linha.

$\mathrm{Na}$ Espanha, o multifacetado professor Armando Torrent defendeu uma postura muito similar, na qual mostra a continuidade historiográfica do Direito Romano no atual Direito europeu comunitário ${ }^{58}$.

Uma última linha na romanística europeia, muito vinculada à anterior, mas ainda mais ambiciosa, é a de Ernst Rabel, discípulo de Mitteis. Rabel defendeu que o Direito Romano tinha que ser a base de um Direito privado unificado de caráter universal ${ }^{59}$. Este projeto, contudo, caiu no esquecimento pela dificuldade de sua elaboração.

\footnotetext{
${ }^{53}$ NÚÑEZ PAZ, María Isabel. Derecho romano, Derecho común y contratación en el marco de la Unión Europea. Oviedo: Universidad de Oviedo, 2000.

${ }^{54}$ FERNÁNDEZ DE BUJÁN, Federico. Contribución del Derecho romano en la futura elaboración de un Thesaurus jurídico europeo. In: Actas de las IV Jornadas de Derecho e Informática. Madrid, 1991. p. 217-223; e FERNÁNDEZ DE BUJÁN, F. Aportación del Derecho romano al proceso de elaboración del Derecho de la Unión Europea. In: Libro homenaje a Jesús López. Medel. t. II. Madrid: Centro de Estudios Registrales: 1999. p. 1757-1772.

${ }^{55}$ LUCHETTI, Giovanni; PETRUCCI, Aldo (ed.). Fondamenti di diritto contrattuale europeo. Dalle radici romane al progetto dei PECL della Commissione Lando. Bologna: Pàtron, 2006.

${ }^{56}$ CATAlAnO, Pierangelo. Diritto e persone. Studi su origine e attualità del sistema romano. Torino: Giappichelli, 1990. p. 161-178. Em espanhol, é possível ler: CATALANO, P. Sistemas jurídicos: Sistema jurídico latinoamericano y Derecho Romano. Revista de Legislación y Jurisprudencia, III, p. 161-178, 1982.

${ }^{57}$ SCHIPANI, Sandro (coord.). Diritto romano, rivoluzioni, codificazioni. Index, Quaderni Camerti di Studi Romanistici, n. 14, 1986. Esta revista, editada em Napoli, é o órgão de difusão desta curiosa visão "neopandectista" italiana.

${ }^{58}$ TORRENT, Armando. Fundamentos del Derecho europeo. Ciencia del Derecho: Derecho romano - ius commune - Derecho europeo. Madrid: Edisofer, 2007.

${ }^{59}$ RABEL, Ernst. El fomento internacional del Derecho privado. Revista de Derecho privado, n. 18, 1931, p. 42 et seq., onde escreveu o seguinte: "para nosotros (es decir, los pueblos abarcados por el sistema romano, a diferencia de los abarcados por el inglés o el islámico) el Derecho romano todavía no es sólo un tónico, sino uno de los elementos de vida que, llamados hormones, se reparten por todo el organismo, favoreciendo el crecimiento y el desarrollo de nuevas formas, o conteniéndolo... El romanismo práctico es el lazo de unión entre los pueblos, y es el más fuerte, a pesar de que casi en todas partes está despojado del poder temporal, y a pesar
} 
A linha historiográfica que a obra de Rabel propôs estava na linha de uma história do Direito universal de cunho claramente oitocentista, e é observável em algumas universidades hispano-americanas, sem que tenha dado maiores frutos ${ }^{60}$. Todavia, a aspiração universal do Direito foi cultivada na Espanha pelo romanista Rafael Domingo, discípulo de Álvaro d'Ors. Domingo coordenou uma vasta obra sobre os "Juristas universais" 61 e, recentemente, estabeleceu as bases de um "Direito global"62.

O Direito global pretende superar a ideia de Direito internacional e a de Direito universal de Mitteis. Para Domingo, o Direito global não deve embasar-se na soberania dos Estados - como faz até agora o Direito internacional -, mas na dignidade das pessoas: o Direito nasce da pessoa ("ex persona oritur ius"). A contribuição deste professor está muito articulada conceitual e juridicamente e toma a base romanística para construir um Direito personalista e flexível, que se abre ao Direito oriental na medida que este converge com um Direito europeu de base romanística ${ }^{63}$.

Certamente, a posição de Rafael Domingo constitui um aporte (e o tempo dirá se será superação) crítico à Romanística a partir da Romanística. Este autor tenta superar o esquema da Neopandectística por meio de um Direito Romano construído a partir de uns princípios aforísticos universais que o livram da restrição estatal. Os trabalhos mais recentes deste romanista espanhol são uma amostra patente da metamorfose crítica que desenvolveu o Direito Romano sem tocar boa parte de seu conteúdo material.

\subsubsection{A corrente neo-humanista}

O que aqui foi agrupado sob o rótulo de "corrente neo-humanista" constitui um grupo de tendências que se diferenciam da visão neopandectista pelo fato de que o Direito Romano

\footnotetext{
de que tiene que dividirse el dominio sobre los espíritus con muchos otros poderes. Su misión más noble sería ser cada vez más el punto de partida para un nuevo Derecho mundial, y dejarse absorber por un nuevo ius gentium privado" - cópia do estudo preliminar [ao livro de Zimmermann], de I. Cremades Ugarte, cit. [nota 50 supra], p. 17.

${ }^{60}$ MARGADANT, Guillermo F. Introducción a la Historia Universal del Derecho. t. I. Xalapa: Universidad Veracruzana, 1974.

${ }^{61}$ DOMINGO, Rafael. Juristas universales. 4 v. Madrid: Marcial Pons, 2004.

${ }^{62}$ DOMINGO, Rafael (coord.). Principios de Derecho global: 1000 reglas jurídicas y aforismos comentados. Navarra: Thompson Reuters Aranzadi, 2006; e DOMINGO, Rafael. ¿Qué es el Derecho global? Navarra: Thompson Reuters Aranzadi, 2008. Esta última obra foi traduzida recentemente ao inglês: DOMINGO, Rafael. The New Global Law. Cambridge: Cambridge University Press, 2010.

${ }^{63}$ DOMINGO, Rafael. Principios de Derecho global: 1000 reglas jurídicas y aforismos comentados. Navarra: Thompson Reuters Aranzadi, 2006.
} 
já não é, para elas, um sistema ou um conjunto de princípios, regras e aforismos que devem ser aplicados, mas um trabalho histórico-filológico ou humanístico. Como tal, distancia-se da sistemática e reconhece o valor histórico e cultural do conhecimento das fontes romanas e sua projeção.

Para começar, deve-se dizer que esta distinção não é completamente categórica, embora expositivamente eficaz, posto que permite mostrar com claridade a distinção entre os que buscam a aplicação do Direito Romano (ou seja, que o veem como algo vigente, apesar das mutações e metamorfoses) e os que querem extrair a mensagem (e não tanto o conteúdo) para a formação dos juristas.

Distinguirei aqui duas aproximações. Uma delas é a denominarei histórico-filológica, que dá especial ênfase ao estudo das fontes do Direito Romano e é a continuadora do método filológico-crítico que começou a gerar-se no século XIX, seguindo as diretrizes dos humanistas. A outra corrente é a histórico-cultural, que busca historiar a tradição romanística como um elemento fundamental da cultura ocidental e é entendida, inclusive fenomenologicamente, como uma viagem iniciática e propedêutica que todo jurista deve empreender.

\subsubsection{A aproximação histórico-filológica}

Conforme diz a professora Rosario de Castro, "a publicação, ao final do século XIX, do Edictum Perpetuum (1883) e da Palingenesia Iuris Civilis (1889), de Lenel, assim como a obra de Gradenwitz, Interpolationen in der Pandekten (1887) foi o ponto de partida deste movimento científico" ${ }^{64}$. Certamente, essas obras atualizavam uma tendência que já no século XVI, com o humanismo jurídico, teve grande esplendor.

Esta aproximação não deu frutos historiográficos diretamente, mas por meio das obras sintéticas que voltavam a configurar a composição histórica do Direito Romano à luz das novas investigações. Devem ser destacados, fundamentalmente, três métodos de aproximação histórico-filológica: a palingenesia crítica, o método das interpolações e a história da transmissão textual. Antes de passar aos resultados historiográficos, comentarei brevemente seu alcance.

\footnotetext{
${ }^{64}$ CASTRO CAMERO, Rosario. de. Consideraciones en torno a la docencia y a la investigación romanísticas en el marco del Espacio Europeo de Educación Superior: II. Investigación. Annaeus: Anales de la tradición romanística, Sevilla, vol. 2, p. 580, 2005.
} 
A palingenesia crítica, que se inicia com a obra de Lenel, é a que ajuda a exegese de cada um dos fragmentos justinianeus, que foram tomados como um sistema, quando, na realidade, formavam uma antologia de textos procedentes de juristas muito distintos e de épocas muito diversas. Este labor crítico é fundamental frente ao estudo das camadas do Direito Romano e à sedimentação de cada uma delas.

Os trabalhos interpolacionistas foram iniciados por Gradenwitz, ainda que tivessem grandes continuadores, dentre os quais cabe citar Albertario, Guarino, Riccobono e Kaser. Seu método, como é sabido, é o de buscar as alterações dos textos clássicos por meio da análise textual. Talvez o investigador mais importante desta corrente seja Max Kaser ${ }^{65}$. Poderse-ia dizer que a figura de Kaser, no seio desta corrente, distinguiu-se da maioria dos autores, pois criticou os excessos do interpolacionismo, criticando inclusive seus próprios trabalhos de juventude. De fato, o "Konservatismus" que defendeu dos anos setenta em diante pode ser entendido como impugnação ao interpolacionismo extremo.

Por último, deve ser citado como método o estudo da história dos textos. Trata-se de um procedimento usado quase exclusivamente por Franz Wieacker, que coletou e aperfeiçoou o testemunho de Krüger. O mais importante era o estudo dos suportes nos quais se coletava o texto jurídico, de maneira que poderiam ser detectados problemas na transmissão do suporte material.

Os três métodos mostram um importante refinamento técnico de alguns estudiosos romanistas que, grosso modo, continuavam com a divisão temática e metodológica que se deu no século XIX. Os romanistas tinham que saber Direito, latim clássico e vulgar, paleografia, codicologia, epigrafia etc., ao mesmo tempo que, em linhas gerais, não deixavam que os historiadores e os filólogos pusessem suas mãos sobre os textos jurídicos. Esse era um trabalho que poderiam e deveriam fazer por si mesmos, de modo exclusivo.

Não obstante, os trabalhos filológico-críticos dos alemães Lenel, Linneis, Gradenwitz, Wieacker e Kaser, e dos italianos Biondi, Scialoja, Arangio-Ruiz e Burdese, para citar apenas alguns, traduziram-se em obras que renovaram a historiografia do Direito Romano. Alguns deles escreveram sobre a história do Direito público romano, reapropriando-se de uma área que, a partir de Mommsen, foi assumida pelos historiadores. Pode-se citar, por exemplo, as

65 KASER, Max. Römische Rechtsquellen und angewandte Juristenmethode: Ausgewählte, zum Teil grundlegend erneuerte Abhandlungen. Wien; Köln; Graz: Böhlau, 1986. 
obras sintéticas de Arangio-Ruiz ${ }^{66}$, de Riccobono ${ }^{67}$ e de De Francisci ${ }^{68}$. Entre as mais recentes, cabe mencionar os dois volumes de Wieacker ${ }^{69}$. Entre as obras de Direito público romano, sobressaem o manual de Burdese ${ }^{70}$ e, sobretudo, o de Kunkel ${ }^{71}$. A expressiva maioria de obras históricas italianas e alemãs foram traduzidas ao espanhol.

Por sua parte, alguns professores espanhóis preferiram dedicar-se ao estudo da história do Direito Romano e das fontes do que cultivar a dogmática. Em geral, ainda que haja algumas exceções, o cultivo da dogmática e da história do Direito Romano foram se tornando trabalhos incompatíveis. Deixando de lado a publicação das fontes ${ }^{72}$, foram escritos alguns textos sintéticos de história do Direito Romano.

Podemos citar, à guisa de exemplo, os dos professores Ursicino Álvarez Suárez ${ }^{73} \mathrm{e}$ José Arias Ramos ${ }^{74}$, pertencentes a uma geração central no século XX. Juan de Churruca ${ }^{75}$, Juan Miquel $^{76}$, Armando Torrent ${ }^{77}$, César Rascón ${ }^{78}$ e Javier Paricio ${ }^{79}$ são exemplos de autores de manuais mais recentes, que tratam sobre os estudos histórico-textuais dos diferentes autores.

A maioria deles traduziu suas colaborações e as dos demais à síntese histórica. Por exemplo, os trabalhos do professor Álvaro d'Ors sobre epigrafia e palingenesia ${ }^{80}$ e o trabalho

\footnotetext{
${ }^{66}$ ARANGIO-RUIZ, Vincenzo. Storia del diritto romano. Napoli: Jovene, 1931. Tradução ao espanhol: ARANGIO-RUIZ, V. Historia del Derecho romano. Madrid: Reus, 1943.

${ }^{67}$ RICCOBONO, Salvatore. Lineamenti della Storia delle Fonti e del Diritto Romano. Compendio del Corsi di Storia e d'esegesi del Diritto Romano. Milano: Giuffrè, 1949.

${ }^{68}$ FRANCISCI, Pietro de. Sintesi storica del diritto romano. Roma: Bulzoni, 1968; e FRANCISCI, Pietro de. Storia del diritto romano, Milano: Giuffré, 1940-1941. Edição espanhola: FRANCISCI, Pietro de. Síntesis histórica del Derecho romano. Madrid: Editorial Revista de Derecho Privado, 1954.

${ }^{69}$ WIEACKER, Franz. Römische Rechtsgeschichte. 2 v. München: Beck, 1988 e 2006.

${ }^{70}$ BURDESE, Alberto. Manuale di diritto pubblico romano. Torino: Utet, 1997. Tradução ao espanhol: BURDESE, Alberto. Manual de Derecho público romano. Barcelona: Bosch, 1972.

${ }^{71}$ KUNKEL, Wolfgang. Römische Rechtsgeschichte. Köln; Wien, várias edições [também com Martin Schermaier]. Tradução ao espanhol: KUNKEL, W. Historia del Derecho romano. Barcelona: Ariel, 2003.

${ }^{72}$ D’ORS, Álvaro (ed.). El Digesto de Justiniano. 3 v. Cizur Menor: Aranzadi, 1975; ou GARCÍA GONZÁLES, José María; RASCÓN GARCÍA, César. Ley de las XII tablas. Madrid: Tecnos, 1993.

${ }^{73}$ Uma síntese de dogmática e de história pode ser lida em: ÁLVAREZ SUÁREZ, Ursicino. Instituciones de Derecho romano I. Madrid: Dykinson, 1978.

${ }^{74}$ ARIAS RAMOS, José. Derecho público romano e historia de las fuentes. Valladolid: Ceres, 1979.

${ }^{75}$ CHURRUCA, Juan de; MENTXACA, Rosa. Introducción Histórica al Derecho Romano. Bilbao: Universidad de Deusto, 1987.

${ }^{76}$ MIQUEL, Joan. Historia del Derecho romano. Barcelona: PPU, 1988.

77 TORRENT, Armando. Derecho público romano y sistema de fuentes. Oviedo: Universidad de Oviedo, 1982.

${ }^{78}$ RASCÓN GARCÍA, César. Síntesis de historia e instituciones de Derecho romano. Madrid: Tecnos, 2006.

${ }^{79}$ PARICIO, Javier. Historia y Fuentes del Derecho Romano. Madrid: Centro de Estudios Ramón Areces, 1988.

${ }^{80}$ D’ORS, Álvaro. Epigrafía jurídica de la España romana. Madrid: Instituto Nacional de Estudios Jurídicos, 1953; e D’ORS, Álvaro. El Código de Eurico. Edición y palingenesia. Madrid; Roma: Boletín Oficial del Estado, 1960.
} 
de Juan Miquel sobre os erros mecânicos na transmissão do Digesto ${ }^{81}$ propuseram importantes inovações que configuraram a atual historiografia do Direito Romano.

Deve-se recordar que todas essas contribuições são avanços na historiografia interna do Direito Romano, que se move na mesma direção desde o chamado humanismo jurídico. Trata-se, como já se disse, de uma historiografia interna, construída exclusivamente por romanistas, cujo avanço é linear e unidimensional. Apesar da diferença das épocas, este método segue as premissas do positivismo rankeano: acumulação de dados e conhecimento de fontes.

Há uma obra muito recente que recolhe boa parte destes avanços, solidificando a historiografia e seguindo esta metodologia: trata-se do trabalho de José María Coma Fort sobre as coleções de fontes que precederam o Corpus Iuris ${ }^{82}$. É um trabalho de grande erudição, que serve como balanço sobre os conhecimentos atuais sobre o Direito préjustinianeu.

\subsubsection{A aproximação histórico-cultural}

A história do Direito Romano pode ser cultivada, também, a partir de um ponto de vista da história das ideias ou das tradições. Trata-se de uma função eminentemente cultural, que reivindica a projeção do Direito Romano sobre o Direito moderno e contemporâneo. Neste sentido, a chamada história das fontes não interessa tanto quanto a tradição propriamente dita.

Assim, se um texto do Digesto foi interpretado de uma determinada maneira e logo se descobre que seu verdadeiro sentido era outro - porque a palingenesia dá provas confiáveis para os que cultivam o método histórico-crítico, trata-se de uma grande descoberta e uma aproximação à verdade. Por outro lado, para os que defendem a importância da visão histórico-cultural, o importante é a projeção de ideias e das instituições romanas, para além dos critérios de verossimilhança a partir dos quais são estudadas. Esta aproximação pode ter um sentido um tanto conservador se busca a ideia de "tradição romana" para explicar de onde surge o Direito atual e a use para legitimá-lo.

\footnotetext{
${ }^{81}$ MIQUEL, Joan. Mechanische Fehler in der Digestenüberlieferung. Zeitschrift der Savigny Stiftung für Rechtsgeschichte, R. A. 80, 1963.

${ }^{82}$ COMA FORT, J. M. Índice comentado de las colecciones de fuentes del Corpus Iuris Civilis. Cizur Menor: Thompson-Aranzadi, 2008.
} 
Os que se mostram mais propensos a esta opção histórico-cultural são os autores que se preocuparam com os aspectos propedêuticos na formação do jurista. Destacarei, por exemplo, a opinião de Pugliese ${ }^{83}$, que salienta que atualmente, depois de desenvolver outras funções, o Direito Romano pode ter uma missão formativa, que é a de mostrar aos estudantes como a "herança viva" do "Direito europeu" articula a mentalidade dos juristas. Já o disse há quase cinquenta anos o professor Álvaro d'Ors, que destacou o valor propedêutico do Direito Romano para a formação de uma mentalidade flexível e sensível historicamente, ao tempo que era um argumento para distanciar o jurista do Direito positivo e vigente ${ }^{84}$.

Devem ser distinguidos os que enfatizam o uso histórico-cultural da "tradição romanística" dos que consideram que a dita história cultural serve para configurar o Direito atual. Os primeiros aproximam-se muito da ideia "neopandectista", pois traçam uma história na qual o Direito Romano não se interrompe substancialmente na codificação. Os segundos valorizam o caráter histórico e temporal da tradição romanística e defendem, como Pugliese, que o Direito Romano é um legado cultural ${ }^{85}$.

Entre os primeiros, destaca-se - seguindo o impulso indireto, mas onipresente de Wieacker - a obra de Peter Stein ${ }^{86}$. Ela foi aplaudida e reivindicada pelos autores neopandectistas, sem que se depreenda de sua leitura uma aprovação completa de suas teses, ainda que haja uma aproximação substancial. Stein é um romanista e historiador que escreveu uma obra sintética de caráter erudito na qual destaca a influência dos juristas romanos na construção da técnica jurídica moderna.

Para Stein, a técnica jurisprudencial e casuística elaborada pelos juristas romanos foi o modelo a partir do qual todos os juristas posteriores foram educados ${ }^{87}$. Tal foi sua influência que transpôs sua mera função reguladora para converter-se em um dos pilares da cultura europeia. Este autor expõe a evolução do Direito Romano até o século XIX, embora, em sua

\footnotetext{
${ }^{83}$ Ver a contribuição de G. Pugliese: PUGLIESE, G. Il diritto romano nella formazione del giurista, oggi. Convegno organizzato dalla Facoltà di giurisprudenza della II Università di Roma. Milano: Giuffrè, 1989.

${ }^{84}$ D'ORS, Álvaro. Sobre el valor formativo del Derecho romano. In.: D’ORS, Álvaro. Papeles del oficio universitario. Madrid: Rialp, 1961. p. 164 et seq.

${ }^{85} \mathrm{Em}$ alguns casos, esta tendência acaba em uma "apologia", como denunciam: BARCELLONA, Pietro; COTTURRI, Giuseppe. Stato e giuristi tra crisi e riforma. Bari: De Donato, 1974; e SCHIAVONE, Aldo. Storiografia e critica del diritto: per una 'archeologia' del diritto privato moderno. Bari: De Donato, 1880.

${ }^{86}$ STEIN, Peter. Roman law in European history. Cambridge: Cambridge University Press, 1999. Tradução ao espanhol: STEIN, Peter. El Derecho romano en la historia de Europa. Historia de una cultura jurídica. Madrid: Siglo XXI Editores, 2001.

${ }^{87}$ Ver: VACCA, Letizia. La giurisprudenza nel sistema delle fonti del diritto romano. Torino: Giappichelli, 1989.
} 
última epígrafe, estenda sua consideração até o século $\mathrm{XX}$, fazendo referência à atual construção do Direito europeu ${ }^{88}$.

Neste sentido também escreveu o historiador Van Caenegem ${ }^{89}$; outros autores, como o romanista Carlo Augusto Cannata ${ }^{90}$ e, de uma forma mais matizada, o historiador Adriano Cavanna ${ }^{91}$, fizeram importantes contribuições ao trabalho de síntese desta tradição romanística desde a recepção do Direito justinianeu até praticamente nossos dias. Cannata ${ }^{92}$ defende uma história do Direito Romano e sua recepção feita a partir de grandes traços e de uma sociologia das mentalidades, oposta - como se verá - a de Schiavone, que busca a microfísica e procura diferenciar os perfis individuais de cada um dos juristas.

Um livro relativamente recente da professora Lauretta Manganzani tenta estudar a formação histórico-cultural do Direito Romano a partir dos textos e de sua projeção ${ }^{93}$. Na Espanha, a aproximação recobre um caráter mais cultural e menos filológico-textual, de modo que não serve tanto para a fundamentação de uma história do Direito Romano que chegue quase aos nossos dias, mas para enfatizar os valores ${ }^{94}$ que se encontram no Direito Romano. Nesta linha, devem ser citados, na Espanha, os documentados trabalhos dos professores Alejandrino Fernández Barreiro ${ }^{95}$ e Javier Paricio ${ }^{96}$.

Recentemente, Manuel J. García Garrido e Federico Fernández de Buján, dois reconhecidos romanistas espanhóis, elaboraram um manual ${ }^{97}$ no qual explicam as origens greco-romanas da democracia e das categorias jurídico-administrativas, em uma obra que

\footnotetext{
${ }^{88}$ STEIN, Peter. Roman law in European history. Cambridge: Cambridge University Press, 1999. p. 128 et seq. ${ }^{89}$ CAENEGEM, Raoul Charles van. European Law in the Past and the Future. Cambridge: University Press, 2002. Tradução ao espanhol: CAENEGEM, R. van. Pasado y futuro del Derecho europeo: dos milenios de unidad y diversidad. Madrid: Civitas, 2003.

${ }^{90}$ CANNATA, Carlo Augusto. Lineamenti di storia della giurisprudenza europea: I. La giurisprudenza romana e il passaggio dall'Antichità al Medioevo. Torino: Giappichelli, 1976; e CANNATA, C.; GAMBARO, Antonio. Lineamenti di storia della giurisprudenza europea: II. Dal Medioevo all'epoca moderna. Torino: Giappichelli, 1989.

${ }^{91}$ CAVANNA, Adriano. Storia del diritto moderno in Europa: Le fonti e il pensiero giuridico. Milano: Giuffrè, 1982.

${ }^{92}$ As últimas obras de A. Cannata são: CANNATA, Carlo Augusto. Materiali per un corso di fondamenti del diritto europeo. 2 v. Torino: Giappichelli, 2005, 2008.

${ }^{93}$ MAGANZANI, Lauretta. Formazione e vicende di un'opera illustre. Il corpus iuris nella cultura del giurista europeo. Torino: Giappichelli, 2002.

${ }^{94}$ Ver, por exemplo: LATORRE, Ángel. Valor actual del Derecho romano. Barcelona: Diresa, 1979.

${ }^{95}$ FERNÁNDEZ BARREIRO, Alejandrino. La tradición romanística en la cultura jurídica europea. Madrid: CEURA, 1992; e FERNÁNDEZ BARREIRO, A. El factor jurisprudencial como elemento de identidad de la cultura jurídica europea: proyección histórica de la herencia jurídico-cultural romana. Granada: Comares, 1998.

${ }^{96}$ Por exemplo, seu recente trabalho: PARICIO, Javier. El legado jurídico de Roma. Madrid: Marcial Pons, 2010. Ver, também: FERNÁNDEZ BARREIRO, A.; PARICIO, Javier. Historia del Derecho romano y su recepción europea. $4^{\mathrm{a}}$ ed. Madrid: CEURA, 2000.

${ }^{97}$ FERNÁNDEZ DE BUJÁN, Federico; GARCÍA GARRIDO, Manuel Jesús. Fundamentos clásicos de la democracia y la administración. Madrid: Ed. Académicas, 2010.
} 
pretende transmitir o legado "a partir da contemplação dessas experiências clássicas - e, por isso, perenes" - do Direito da Antiguidade.

Trata-se, em suma, de buscar os valores humanísticos do Direito Romano, os quais configuraram o legado cultural do Direito europeu. Em um trabalho recentíssimo, o historiador José Manuel Pérez-Prendes referiu-se - muito astuciosamente - às "bemaventuranças do Direito" 98 . O Direito Romano, para este professor, gerou frutos de prosperidade para a cultura europeia. Em seu livro, destaca cinco, os quais se aperfeiçoaram a partir da civilização romana: a criação de marcos de convivência; a repetição e a consolidação de hábitos sociais; a arte de infundir justiça e equidade; a solidificação das figuras jurídicas surgidas; e o fomento da metamorfose jurídica sem deixar de buscar a justiça.

Em síntese, trata-se de uma apologia ao Direito como elemento formativo e propedêutico para a educação dos juristas. A obra do professor Pérez-Prendes exemplifica muito bem esta direção.

\subsubsection{A investigação "ad intra": um rápido balanço.}

Nas páginas precedentes, foram examinadas algumas correntes "ad intra" dos estudiosos do Direito Romano. Viu-se como a dogmática se transformou paulatinamente em uma história dos Direitos privados, no marco da configuração jurídica da União Europeia. A visão "neopandectista" buscou a metamorfose do Direito Romano nos ordenamentos atuais, o que implica, também, um repensar a questão à luz de outros ordenamentos e um diálogo necessário da dogmática romanística com os Direitos civis e mercantis europeus. Ao romanista que eleja esta senda não há, portanto, outra alternativa, senão um trabalho com os jusprivatistas.

Por outro lado, a direção empreendida pelos que estudam o Direito Romano por meio do método histórico-crítico exige, atualmente, uma complementação com os trabalhos dos filólogos. Assim, como explica Fernando Betancourt ${ }^{99}$, hoje, o Direito Romano se vê

\footnotetext{
${ }^{98}$ PÉREZ-PRENDES, José Manuel. Las bienaventuranzas del Derecho romano. Madrid: Iustel, 2010.

${ }^{99}$ BETANCOURT SERNA, Fernando. Líneas de investigación romanística. Estado de la cuestión. In: BRAVO, Ramón Herrera; REVUELTA, María Salazar. Problemática del Derecho Romano ante la implantación de los nuevos planes de estudio. Jaén: Universidad de Jaén, 1999. p. 77-86.
} 
obrigado a trabalhar de forma interdisciplinar com os filólogos. Deve-se acabar, então, com a separação entre os latinistas e os romanistas ${ }^{100}$. Isso supõe um avanço crítico fundamental.

De outra parte, a superação da dogmática ao estilo de Schultz como obra histórica representou um importante estímulo crítico promovido por autores importantes como Riccardo Orestano ${ }^{101}$. Este professor defendeu a historicidade como o caráter substancial donde se reflete o jurídico. A reflexão historicista de Orestano foi levada pelo autor a terrenos filosóficos, abrindo, como outros romanistas, uma via "ad extra", da qual nos ocuparemos a seguir.

Na Espanha, nestas linhas destacam-se os esforços do romanista e filólogo F. J. Andrés Santos, que se dedicou principalmente à tradução comentada de fontes clássicas, na qual convergem e se interpenetram as duas facetas deste professor ${ }^{102}$. Em alguns trabalhos, destacou a problemática de como os bizantinos solucionaram o problema de trabalhar com algumas fontes jurídicas escritas em latim que deveriam ser aplicadas em um território de língua grega ${ }^{103}$. Este tipo de estudos, nos quais a filologia e o Direito iluminam-se entre si, são um modelo de estudo interdisciplinar que acaba com a distinção entre filólogos e juristas ao manipular textos.

\subsection{A INVESTIGAÇÃO “AD EXTRA”}

Sob a denominação de "investigação 'ad extra", agrupam-se uma série de correntes cultivadas pelos romanistas em colaboração com especialistas de outros conhecimentos, ou mesmo pelos romanistas isoladamente, mas após abrirem-se à interdisciplinaridade. As áreas beneficiadas pela abertura destes romanistas são, fundamentalmente, a filosofia, a filologia, a história e a antropologia.

\footnotetext{
100 Alguns romanistas querem conservar sua parcela, preservando os frutos da divisão oitocentista. Ver: HERNÁNDEZ-TEJERO JORGE, Francisco. El latín y los juristas. In: ESTEVE, Jaime Roset. Estudios en homenaje al Profesor Juan Iglesias. Madrid: Universidad Complutense, 1988. p. 353-358.

${ }^{101}$ ORESTANO, Riccardo. Introduzione allo studio del diritto romano. Bologna: Il Mulino, 1987.

102 Por exemplo, o trabalho interdisciplinar levado a cabo em colaboração com o filólogo J. Signes Codoñer deu lugar ao volume: ANDRÉS SANTOS, Francisco Javier; SIGNES CODOÑER, Juan. La introducción al Derecho (Eisagoge) del Patriarca Focio. Madrid: CSIC, 2007.

${ }^{103}$ ANDRÉS SANTOS, Francisco Javier. Algunos problemas de traducción de la terminología jurídica romana en el Imperio Bizantino. Minerva: Revista de filología clásica, n. 19, p. 285-296, 2006.
} 
Dividi estas visões em dois grandes grupos. O primeiro deles encontra-se sob o título genérico de "histórico-contextualista", que não tem a ver com a "Escola de Cambridge"104, mas com a interpretação histórica do Direito Romano a partir de seu contexto político, social e cultural. Um grupo de correntes dá ênfase na leitura que fazemos atualmente dos autores romanos, ou seja, salientam a posição do sujeito historiador frente à historicidade do Direito Romano. Outro grupo de correntes ocupa-se com o contexto em si, isto é, não tanto com a recepção e com o ponto de vista do historiador quanto com o peso da história econômica, social e política para explicar a evolução do Direito em Roma.

Por isso, denominarei o primeiro grupo de correntes de "subjetivista", uma vez que se fundamentam na visão hermenêutica e fenomenológica do Direito Romano, enquanto o segundo grupo de correntes, chamarei simplesmente de "objetivista", porque considera de forma multidisciplinar os textos e os contextos nos quais se desenvolveu o Direito Romano.

O segundo grande grupo engloba as correntes que podem ser resumidas sob a denominação "antropológico-crítica". Podem ser distinguidas duas vertentes: a primeira, centrada na análise genealógica e arqueológica, seguindo a obra de Foucault e do estruturalismo, e a segunda, propriamente dedicada à antropologia jurídica, de caráter histórico e com uma maior vocação comparatista.

\subsubsection{A corrente histórico-contextualista}

O problema exegético do Direito Romano pode desembocar em uma questão muito mais ampla e prévia, que é de como interpretar. Alguns autores dedicaram-se ao estudo do Direito Romano a partir do contexto no qual se formou. Se os estudiosos aceitam que o Direito Romano pode ser estudado da mesma maneira que o Direito contemporâneo, ou seja, aplicando uma metodologia historiográfica similar, eles acabam estudando seu desenvolvimento de uma maneira objetiva, isto é, aplicando os esquemas mentais do estudioso à realidade do Direito Romano.

Em contrapartida, os autores que consideram que o Direito Romano não pode ser estudado a partir de categorias atuais, sendo necessário proceder a uma interpretação

\footnotetext{
${ }^{104}$ A Escola de Cambridge - cujos membros mais eminentes são J. Pocock, J. Lasslet e Q. Skinner - advoga pelo "contextualismo" como técnica de estudo da história do pensamento político. Para eles, o contexto ajuda a compreender o significado dos textos históricos de uma forma mais realista e em concordância com o que o autor diria de si mesmo e de seus propósitos.
} 
hermenêutica, denominei-os "subjetivistas". Nesta linha, colaboram a fenomenologia e a hermenêutica como métodos de aproximação filosófica ao objeto de estudo. Ambas as correntes têm um caráter histórico, pois pretendem estudar o Direito Romano e sua projeção de acordo com uma perspectiva histórica que atenda não só à reconstrução do objeto de estudo, mas, também, à sua interpretação como tal.

\subsubsection{Subjetivista}

O primeiro romanista que se interessou pelo problema da subjetividade na interpretação histórica foi Emilio Betti. Este autor italiano, que era também filósofo e teólogo, apresenta o problema do ponto de vista no estudo Direito Romano. Algumas obras de juventude mostram este problema ${ }^{105}$. Betti, em si, nunca foi um pensador que defendia a subjetividade: ao contrário, ele cria que era necessária a correspondência (a univocidade) entre o significante e o significado.

Precisamente, percebendo que, em muitos casos não era possível, tentou abrir o estudo jurídico a uma preocupação filosófica mais geral. Não entrarei aqui em sua formulação jusfilosófica, em seu Tratado geral da intepretação nem em sua controvérsia com H. G. Gadamer, pois isso excederia os limites da problemática da historiografia romanística.

Em vez disso, deve-se abordar o discurso "Direito Romano e dogmática moderna”, de 1927, no qual se pode ler o seguinte:

Ao afirmar a relatividade histórica de cada reconstrução de ordenamentos jurídicos
passados, não tento negar o valor objetivo de uma reconstrução dogmática dirigida
em acordo com os critérios aqui defendidos, o qual levaria a suprimir a distinção
entre reconstruções boas e reconstruções más (i.e., de valor puramente subjetivo).
Uma boa reconstrução, de fato, embora seja subjetiva como produto espiritual
historicamente condicionado, é também, objetiva como valor: dessa maneira que o
sentido histórico é antes subjetivo como sentido, ou seja, como forma do espírito,
mas é objetivo como medida de avaliação. Explicar, por outro lado, em quais
condições e por qual razão profunda a nossa subjetividade - nosso espírito e nossa
experiência - consegue, em geral, alcançar a máxima objetividade, é um problema
que está fora da tarefa bem circunscrita que eu havia proposto... Explicar tudo isso,
de fato, não é possível sem enfrentar e resolver o problema gnosiológico prévio e
fundamental acerca do valor de nosso conhecimento. Conhecimento que já havia
sido entendido como "assimilação congenial do objeto por parte do sujeito", na

105 BETTI, Emilio. La restaurazione Sullana e il suo esito (Contributo allo studio della crisi della costituzione repubblicana in Roma). Pavia: Mattei \& C, 1915; BETTI, Emilio. La struttura dell'obbligazione romana e il problema della sua genesi. Milano: Giuffrè, 1919; BETTI, Emilio. Il concetto della obbligazione costruito dal punto di vista dell'azione. Pavia: Tip. Cooperativa, 1920; BETTI, Emilio. Trattato dei limiti soggettivi della cosa giudicata in Diritto romano. Macerata: Tip. Bianchini,1922. 
perspectiva, recém confirmada, de que "não se trata de desconhecer a historicidade do objeto, mas se trata de reconhecer a historicidade do sujeito ${ }^{106}$.

O problema apresentado por Betti é, em última instância, a grande questão hermenêutica que antecede todo estudo historiográfico: "como se pode conhecer o passado?", "pode o historiador liberar-se das categorias e das pré-compreensões do presente para abordar o estudo do passado?". Os estudos deste autor geraram uma grande variedade de linhas críticas. Pode-se dizer, exagerando-se um pouco, que Betti foi o primeiro romanista que apresentou os problemas epistemológicos prévios ao estudo historiográfico do Direito Romano.

Alguns romanistas reapresentaram a postura hermenêutica de Betti, que defendia o valor das fontes romanas, e, ao mesmo tempo, a impossibilidade de conhecê-las por nossa configuração atual das categorias jurídicas. Não se deve confundir a posição deste autor com a dos neopandectistas, pois ele considerava que não podíamos nos livrar da tradição, não que a tradição fosse o caminho a seguir ${ }^{107}$. Nesta via aberta pelo romanista e filósofo italiano podemos situar outros quatro importantes romanistas que, de forma distinta, deram respostas às questões suscitadas por Betti ${ }^{108}$.

Em primeiro lugar, Riccardo Orestano, que repensou a metodologia da história do Direito Romano. Para isso, distinguiu seis significados distintos de "Direito Romano": como Direito histórico, considerado "stricto sensu"; como tradição romanista; como Direito comum; como "Direito Romano atual" ou "Pandectística" ao estilo oitocentista; como Romanística; como romanismo, próximo ao sentido que denominei como "históricocultural"109.

Orestano distinguiu analiticamente todos esses significados escondidos sob o rótulo de Direito Romano. Com isso, queria mostrar a historicidade do Direito Romano e a impossibilidade de se escapar de todas essas denominações - que haviam obtido êxito na

\footnotetext{
${ }^{106}$ CRIFÒ, Giuliano. Emilio Betti y la cultura jurídica. A propósito de la edición chilena de la interpretación jurídica. Revista Chilena de Derecho, v. 34, n. 1, p. 163-179, 2007.

${ }^{107}$ BETTI, Emilio. Storia e dogmatica del diritto. In.: I Congresso Internazionale della Società Italiana di Storia del Diritto. La storia del diritto nel quadro delle scienze storiche. Atti del primo Congresso internazionale. Firenze: Leo S. Olschki, 1966. p. 106 et seq.

${ }^{108} \mathrm{Na}$ Espanha, pode-se ver o balanço crítico de: PETIT CALVO, Carlos. El romano de Pompeyo o hic sunt leones. Anuario de Historia del Derecho Español, n. 69, p. 563-606, 1990.

${ }^{109}$ ORESTANO, Riccardo. Il diritto romano nella scienza del diritto. Jus, ano II, fasc. II, Milano, Università Cattolica del Sacro Cuore, p. 141-178, esp. p. 144, 1951.
} 
disciplina - no momento de estudar o Direito Romano. O romanista deveria conviver com todos esses influxos e ser consciente disso ${ }^{110}$.

Em segundo lugar, farei referência a Bernardo Albanese, o qual, seguindo de forma radical os planejamentos de Betti, considerou que, no estudo atual do Direito Romano, os conceitos jurídicos construídos na Modernidade só podiam ser usados se estavam construídos especificamente pelo jurista moderno ou contemporâneo, pensando exclusivamente na terminologia e nos conceitos romanos ${ }^{111}$.

Também em estrita consonância com a linha metodológica e historiográfica de Betti, encontra-se, em uma geração muito posterior, Giuliano Crifò. Este professor, assim como os seguidores da hermenêutica bettiana, mostra-se muito crítico à "Neopandectística" e, em resposta a ela, reclamava uma radicalização da historiografia contra a assunção atual dos modelos continuístas, nos quais o Direito Romano continua como um Direito aplicável e vigente $^{112}$.

O mais filosófico dos romanistas atuais quiçá seja Mario Bretone, que considerou que o Direito Romano é um fenômeno técnico e que deve ser explicado por meio de uma imersão no sentido histórico-cultural ${ }^{113}$. Por isso, opôs-se firmemente à Neopandectística, da mesma maneira que se enfrentou, ao seu tempo, a história dogmática de Schultz, que - sob seu ponto de vista - não estudava os juristas, mas sua ciência, de uma forma completamente abstrata. Assim mesmo, Bretone acreditava que Schultz estava completamente equivocado ao conceber o Direito dos juristas romanos como um saber totalmente afastado dos demais, especialmente da filosofia ${ }^{114}$

Com a obra de Bretone, aprofunda-se na corrente de Betti e, ao mesmo tempo, aproxima-se da visão contextualista, sobre a qual se falará a seguir. Em sua vertente mais fenomenológica, este autor italiano se refere ao tempo como um problema na construção histórica. Em uma via intermediária entre Betti e Gadamer, Bretone propõe estudar o Direito Romano de forma oposta à Neopandectística. Considera que os juristas romanos não

\footnotetext{
${ }^{110}$ ORESTANO, Riccardo. Diritto, incontri e scontri. Bologna: Il Mulino, 1981. p. 145 et seq.

111 ALBANESE, Bernardo. Premesse allo studio del diritto romano. Palermo: Università di Palermo, 1978. p. 19.

${ }^{112}$ CRIFÒ, Giuliano. Pandettisti e storicisti nel Diritto romano oggi en Diritto Romano attuale. Storia, Metodo, Cultura nella Scienza Giuridica, n. 1, p. 23-28, 1999. Ver, também: CRIFÒ, Giuliano. Il compito del romanista. Revista internacional de Derecho romano, p. 01-42, 2008.

${ }^{113}$ BRETONE, Mario. Diritto e tempo nella tradizione europea. Bari: Laterza, 1999; e BRETONE, Mario. Derecho y tiempo en la tradición europea. México: Fondo de Cultura Económica, 2001.

114 BRETONE, Mario. Postulati e aporie nella History di Schultz. In: AAVV. La giurisprudenza romana nella storiografia contemporanea. Bari: Cacucci, 1982.
} 
poderiam pensar nas categorias criadas posteriormente, e que nossa tradição não pode dar conta dessas categorias como uma extrapolação das nossas ${ }^{115}$.

Bretone dedicou importantes estudos ao conceito de "tradição", mostrando os problemas de uma leitura excessivamente fenomenológica, ao mesmo tempo que matizou o conceito proposto por outros investigadores ${ }^{116}$. Como é sabido, este conceito adquiriu grande relevância em nossos dias, pois, frente ao multiculturalismo, enfatizou-se a via das tradições como forma fenomenológica de reconhecimento individual e coletivo.

Nesta via, por exemplo, o romanista Alan Watson estudou as diferentes tradições jurídicas, mostrando interesse em enfatizar as áreas comuns entre elas. Crê que a supremacia cultural do Direito Romano a distingue das demais ${ }^{117}$, mas, em seus textos, dedica especial cuidado ao exame das tradições do Direito japonês, do Direito canônico clássico, do Direito chinês antigo, do Direito bíblico e do Direito islâmico, tal como faz, de uma forma um pouco diversa, Rafael Domingo.

Em particular, Watson tem uma concepção crítica do Direito Romano, e crê que o Direito Romano não foi uma obra perfeita e que poderiam ser estabelecidas outras concepções históricas tão ou mais elaboradas. Para ele, a atividade dos juristas romanos era um puro exercício intelectual, ou seja, não um sistema, mas fazer interpretações segundo regras desenhadas por eles mesmos ${ }^{118}$.

Trata-se, em síntese, de uma questão técnica, não de um "saber". Esta é uma impugnação epistemológica que Watson e Bretone ${ }^{119}$ compartilham com outros seguidores da visão fenomenológica e hermenêutica do Direito Romano. Esta corrente, como tentarei mostrar abaixo, é levada por Aldo Schiavone ao campo da genealogia foucaultiana.

Em suma, todos esses autores, abertos a problemas filosófico-hermenêuticos, fizeram uma contribuição fundamental ao diálogo da Romanística com a filosofia continental. $\mathrm{Na}$ Espanha, a recepção destas ideias é cada vez maior, embora não tenha obtido êxito em todos os âmbitos. Talvez, os que se mostraram mais sensíveis desde o princípio a estas questões

\footnotetext{
${ }^{115}$ BRETONE, Mario. La coscienza ironica della Romanistica. Labeo, Napoli, n. 43, p. 187-201, 1997.

${ }^{116}$ MERRYMAN, John Henry. La tradición jurídica romano-canónica. México: Fondo de Cultura Económica, 1989, p. 17: “...Un conjunto de actitudes profundamente arraigadas, históricamente condicionadas, acerca de la naturaleza del Derecho, acerca del papel del Derecho en la sociedad y en el cuerpo político, acerca de la organización y la operación adecuadas de un sistema legal, y acerca de la forma en que se hace o debiera hacerse, aplicarse, estudiarse, perfeccionarse y enseñarse el Derecho".

${ }^{117}$ WATSON, Alan. Legal History and a Common Law for Europe: Mystery, Reality, Imagination. Stockholm: Olin Foundation for Legal History, 2001.

${ }^{118}$ WATSON, Alan. The Spirit of Roman Law. Athens: University of Georgia Press, 1995. p. 205.

${ }^{119}$ Ver nuances introduzidas por: BRETONE, Mario. Tecniche e ideologie dei giuristi romani. Napoli: Edizioni Scientifiche Italiane, 1982.
} 
foram o professor Armando Torrent ${ }^{120}$ e alguns discípulos seus, como Francisco J. Cuena Boy ${ }^{121}$. Também, graças à tradução de alguns dos trabalhos destes autores à língua espanhola (Orestano, Bretone...), o público espanhol, devido ao esforço de divulgação de alguns romanistas, introduziu-se nesta corrente crítica ${ }^{122}$.

Historiadores como Pedro López Barja de Quiroga também se interessaram pela história do pensamento político em Roma, procurando as intersecções entre a história, a filosofia e o Direito, como se pode ver em uma recente obra dedicada ao estudo da história das ideias políticas no período final da República ${ }^{123}$. Também o romanista J. M. Ribas Alba se dedicou recentemente à história do pensamento em Roma, em um estudo interdisciplinar sobre o conceito de liberdade ${ }^{124}$, muito vinculado a seus trabalhos sobre o Direito eleitoral. Ribas Alba prefere a análise filosófica a partir da história conceitual, que, em alguns pontos por suas elaboradas conexões - aproxima-se da perspectiva filosófica. Trata-se de uma história conceitual crítica, a qual examina e critica a historiografia germanística da Antiguidade.

Gostaria de comentar, por último, que o vínculo entre Direito Romano e filosofia na Espanha resultou, também, em uma importante obra do pensamento romano que leva em conta a formação do Direito: trata-se de Pensamento Romano, de Salvador Mas Torres ${ }^{125}$. As obras anteriores, dedicadas ao pensamento em Roma, ocupavam-se exclusivamente da filosofia teórica, sem afã interdisciplinar algum ${ }^{126}$. Na obra de Salvador Mas pode-se ver a concepção interdisciplinar dos estudos sobre a cultura romana, os quais constituem o outro grupo de correntes da aproximação contextualista.

\footnotetext{
120 TORRENT, Armando. Introducción metodológica al estudio del Derecho romano. Oviedo: Universidad de Oviedo, 1974. p. 121 et seq.

${ }^{121}$ Muito próximo à filosofia jurídica está: CUENA BOY, Francisco. Sistema jurídico y Derecho romano. La idea de sistema jurídico y su proyección en la experiencia jurídica romana. Santander: Universidad de Cantabria, 1998.

${ }^{122}$ Por exemplo, no recente livro (PARICIO, Javier. El legado jurídico de Roma. Madrid: Marcial Pons, 2010) do professor Paricio, são comentadas muitas das ideias de Bretone.

${ }^{123}$ LÓPEZ BARJA DE QUIROGA, Pedro Manuel. Imperio legítimo. El pensamiento político en tiempos de Cicerón. Madrid: Mínimo Tránsito, 2007.

${ }^{124}$ RIBAS ALBA, José María. Libertad. La vía romana hacia la democracia. Granada: Comares, 2009.

125 MAS, Salvador. Pensamiento romano: una historia de la filosofía en Roma. Valencia: Tirant lo Blanch, 2006.

${ }^{126}$ LEVI, Adolfo. Storia della filosofia romana. Firenze: Sansoni, 1949; há tradução castelhana: LEVI, Adolfo. Historia de la filosofía romana. Buenos Aires: Eudeba, 1979.
} 


\subsubsection{Objetivista}

Este grupo de correntes se caracteriza pelo estudo do "Direito Romano" em seu contexto social e cultural. A diferença quanto ao grupo de correntes anterior é de matiz: enquanto aqueles se preocupavam por questões filosóficas e metodológicas, estes preferiram aplicar métodos atuais convencidos de que o debate interdisciplinar ajudaria a corrigir os problemas de enfoque.

O resultado, ao final, mostra exemplos da aplicação de métodos muito distintos, deixando, em muitos casos, um espaço para a narrativa clássica da história de Roma e do Direito Romano. A mudança se dá de forma substancial, não tanto na forma de explicar, mas no debate interdisciplinar entre as diferentes formas de fazê-lo.

Este grupo de correntes gerou-se fundamentalmente graças ao interesse de alguns juristas pelo trabalho de alguns historiadores de Roma. Exposta a delimitação de competência entre ambos, proveniente - como se viu - do século XX, foram alguns romanistas italianos, procedentes do hegelianismo e do marxismo, os que mostraram maior interesse pela interdisciplinaridade. Sua abertura à história, à filologia, à sociologia e à filosofia possibilitou uma renovação substancial da Romanística.

Enquanto a filosofia, a história e a filologia tiveram importantes desenvolvimentos durante a primeira metade do século $\mathrm{X}$, o Direito Romano abriu pouquíssimo suas perspectivas com respeito às do século XIX. Em concreto, pode-se dizer que a história política oitocentista tinha uma grande competidora na história econômica e social, e que a filosofia pós-nietzscheana se fragmentou em uma diversidade de correntes. A filologia clássica havia dado tímidos passos em direção ao marxismo, e a linguística começava a ser estudada de forma bastante inovadora.

A história marxista sobre Roma - iniciada por Rostovtzeff ${ }^{127}$ e continuada durante o mesmo século por autores tão brilhantes quanto, como Kovaliov ${ }^{128}$, Alföldy ${ }^{129}$ e, na Espanha, Gonzalo Bravo ${ }^{130}$ - era um estímulo fundamental para transformar a história política que havia sido escrita na esteira de Mommsen. As obras da historiografia francesa, como as de Petit $^{131}$ e Piganiol ${ }^{132}$, resultavam muito clássicas e pouco "incisivas".

\footnotetext{
${ }^{127}$ ROSTOVTZEFF, M. Historia social y económica del Imperio Romano. Madrid: Espasa-Calpe, 1972.

${ }^{128}$ KOVALIOV, Sergei Ivanovich. Historia de Roma. Madrid: Akal, 1979.

${ }^{129}$ ALFÖLDY, Géza. Historia social de Roma. Madrid: Alianza, 1987.

${ }^{130}$ BRAVO, Gonzalo. Poder político y desarrollo social en la Roma antigua. Madrid: Taurus, 1989.

${ }^{131}$ PETIT, Paul. Historia de la Antigüedad. Barcelona: Labor, 1967.
} 
Na Itália, graças à particular filtragem de elementos hegelianos e marxistas na filosofia e na historiografia, por meio de Labriola (considerado o introdutor do marxismo na Itália), de Gentile e de Croce, esta dupla herança foi recebida, em muitas ocasiões, de forma conjunta ${ }^{133}$. Possivelmente tenha sido Arnaldo Momigliano quem amalgamou a herança neo-hegeliana e neopositivista, fundindo-as em um crisol comum que permitiu dar a volta à historiografia.

A figura de Momigliano permite unir a fragmentação dos saberes e o método histórico-crítico que aprendeu com seu mestre De Sanctis, com a penetração neo-hegeliana da unidade dos saberes ${ }^{134}$, sem deixar de dar atenção aos trabalhos marxistas como os de Rostovtzeff. De certa forma, a atenção de Momigliano à história das ideias é o que lhe permitiu ser a ligação entre a historiografia positivista e os historiadores marxistas posteriores à Segunda Guerra Mundial.

A Storia de Roma de Momigliano e Schiavone ${ }^{135}$ representou uma união palpável entre a historiografia das duas épocas. A obra mais renovadora da disciplina possivelmente foi coordenada por Mario Talamanca em $1975^{136}$, na qual reuniu uma boa plêiade de jovens romanistas de orientação geralmente marxista (Amelotti, Bonini, Brutti, Capogrossi, Càssola, Cervenca, Labruna, Masi, Mazza, Santalucia e o próprio Talamanca).

A influência do marxismo na Itália, em que pese ter se cristalizado nos anos setenta ${ }^{137}$, já estava presente graças à obra do professor tcheco Bartosek, que havia reclamado uma presença interdisciplinar no estudo da Romanística ${ }^{138}$ - para quem os investigadores não deveriam encerrar-se em uma torre de marfim e a docência do Direito Romano deveria ter uma função social para a formação do jurista ${ }^{139}$. As reclamações de Bartosek estavam

\footnotetext{
132 PIGANIOL, André. Historia de Roma. Buenos Aires: EUDEBA, 1961.

${ }^{133}$ MORENO CUÑAT, María José. Algunas consideraciones acerca del idealismo neohegeliano en Italia. Anuario de la Facultad de Derecho Universidad de Extremadura (AFDUE), v. 5, p. 545-556, 1987.

${ }^{134}$ De fato, Momigliano considerou que havia chegado o fim da historiografia jurídica como disciplina separada e autônoma das demais ciências históricas. Ver: MOMIGLIANO, Arnaldo. Le conseguenze del rinnovamento della storia dei diritti antichi. Rivista Storica Italiana, n. 76, p. 133-149, 1964.

${ }^{135}$ MOMIGLIANO, Arnaldo; SCHIAVONE, Aldo (dir.). Storia di Roma. Torino: Einaudi, 1990.

136 TALAMANCA, Mario (ed.). Lineamenti di storia del diritto romano. Milano: Giuffrè, 1979.

${ }^{137}$ Ver síntese de: DUPLÁ ANSUÁTEGUI, Antonio. Notas a propósito de la historiografía neomarxista italiana sobre el mundo clásico. Studia historica. Historia antigua, n. 19, p. 115-142, 2001.

${ }^{138}$ BARTOSEK, Milan. Metodo tradizionale e materialismo storico nella metodologia del diritto romano. In.: Atti del I Congresso Internazionale della Società Italiana di Storia del Diritto. La storia del diritto nel quadro delle scienze storiche. Firenze: Olschki, 1966. p. 95 et seq.

${ }^{139}$ BARTOSEK, Milan. Come si dovrebbe studiare attualmente il diritto romano. Alcune idee. In: Studi in onore di Vincenzo Arangio-Ruiz. Napoli: Jovene, 1953, p. 328-331, p. 337-338: "Ho l'onore di conoscere personalmente la massima parte dei cultori del diritto romano in Europa e perciò posso dire qualche cosa, posso attestare che sono quasi tutti uomini (e oramai anche donne) dotati di altissime qualità morali ed intellettuali, ma prima di tutto gente laboriosissima che vive per la loro scienza, che la consacra ogni pensiero nel tempo
} 
afastadas da visão culturalista do Direito Romano, embora tivessem uma função emancipatória e crítica.

Benjamin e Hauser também abriram as vias comuns entre a história e as artes, e, em particular, a literatura. Com efeito, a literatura latina, separada dos textos históricos e jurídicos, teve uma importante renovação pela mão de autores marxistas, que contribuíram com o estudo holístico e interdisciplinar. Prova disso são os estudos na Itália de filólogos como Canfora sobre a base de Bianchi Bandinelli e seus discípulos Torelli e Carandini. Em particular, Carandini ${ }^{140}$ dedicou-se a reconstruir a história de Roma a partir de sua fundação usando uma pluralidade de métodos filológicos, históricos, arqueológicos etc., os quais lançaram teses tão sugestivas quanto incômodas sobre as origens políticas, sociais e culturais de Roma.

O marxismo, dito de forma muito resumida, ajudou a conectar a história social com a história política e as fundiu em uma explicação materialista da realidade. Os trabalhos interdisciplinares entre arqueólogos, historiadores, juristas e filólogos deram frutos cuja direção se desdobrou frequentemente. Citarei brevemente somente dois importantes âmbitos, a partir dos quais as barreiras começaram a cair: a história constitucional ${ }^{141}$, e o Direito público e a história social e econômica.

Partindo da ideia de Mommsen, foi revisado o conceito de "Constituição romana" formada como o espírito do povo romano. Esta visão foi exposta sob um paradigma acentuadamente materialista por Francesco de Martino em sua monumental história da constituição romana ${ }^{142}$, que influenciou poderosamente, por sua vez, os trabalhos do antropólogo C. Meier ${ }^{143}$ e, na Espanha, as obras do historiador J. M. Roldán ${ }^{144}$ e do romanista Armando Torrent ${ }^{145}$.

disponibile, che passa la loro vita praticamente in studi, biblioteche ed archivi. Ma appunto questa loro passione per la scienza e questo loro modo di vivere piuttosto solitario portano un gran pericolo, cioè di perdere il contatto con altri lavoratori, colla società e suoi bisogni, il pericolo di chiudersi nella «torre d'avorio». Ed è chiaro che se questo pericolo, questa tendenza si realizzerà in una misura considerevole, ciò può e deve influire su tutta la loro creazione".

${ }^{140}$ CARANDINI, Andrea. Remo e Romolo. Dai rionni dei Quiriti alla città dei Romani (775-750 - 700-675 a. C. circa). Torino: Einaudi, 2006.

${ }^{141}$ Ver síntese recente em: DUPLÁ ANSUÁTEGUI, Antonio. La 'Constitución Romana' como mecanismo de inclusión y exclusión. Studia historica. Historia antigua, n. 26, p. 21-38, 2008.

${ }^{142}$ DE MARTINO, Francesco. Storia della Costituzione romana. Napoli: Jovene, 1973.

${ }^{143}$ MEIER, Christian. Introduction à l'anthropologie politique de l'Antiquité classique. Paris: PUF, 1984.

${ }^{144}$ Ver, por exemplo: ROLDÁN HERVÁS, José Manuel. El orden constitucional romano en la primera mitad del siglo II a.C.: de la res publica aristocrática a la res publica oligárquica. Gerión - Revista de Historia Antigua, n. 2, p. 67-100, 1984.

${ }^{145}$ TORRENT, Armando. Derecho público romano y sistema de fuentes. Oviedo: Universidad de Oviedo, 1982. 
O Direito, por sua vez, começava a formar parte da história social e econômica. A história política poderia ser estudada também sob o prisma socioeconômico, e alguns romanistas se permitiram o estudo interdisciplinar. Duas provas disso são os trabalhos coordenados, na esteira do Instituto Gramsci, por Aldo Schiavone ${ }^{146}$, Andrea Giardina e L. Capogrossi Colognesi sobre questões multidisciplinares da sociedade, da economia, da política e do Direito em Roma ${ }^{147}$. Além disso, os trabalhos holísticos de Francesco de Martino ${ }^{148}$ tiveram ampla influência na Romanística. Pode-se dizer que estes autores marxistas, que trabalharam juntos durante a juventude, tomaram sendas cada vez mais individualistas e adotaram, em muitos casos, uma leitura mais estruturalista e pós-moderna, conforme se verá a seguir.

A partir do trabalho interdisciplinar de alguns historiadores de Roma de espírito crítico $^{149}$ (Blázquez, Remesal, Marco Simón, Pina Polo... ${ }^{150}$ ), alguns romanistas espanhóis estudaram as transformações do Direito republicano no Principado e no Dominato ${ }^{151}$, enfatizando o caráter de assembleia do Direito da República e da retórica como uma ars argumentativa que mudou substancialmente na época do Dominato e do Império. Isso deu lugar a uma série de obras sobre o Direito público que convergem com os estudos sobre Direito municipal e urbanístico, por um lado, e sobre o problema da cidadania, por outro. $\mathrm{Na}$ Espanha, sobre Direito municipal e urbanístico, pode-se destacar as obras de José Luis Murga $^{152}$. Atualmente, os professores Gabba e Capogrossi coordenaram um imponente estudo

\footnotetext{
${ }^{146}$ O programa paradigmático pode ser encontrado em: SCHIAVONE, Aldo. Storiografia giuridica e apologia del diritto moderno. Democrazia e Diritto, v. XIII, n. 2, p. 65-86, 1973 - que, depois, passaria a ser o primeiro capítulo de: SCHIAVONE, Aldo. Storiografia e critica del diritto: per una 'archeologia' del diritto privato moderno. Bari: De Donato, 1880 - cujo apêndice acaba apresentando a necessidade de criar-se um novo tipo de Romanística, baseada no trabalho interdisciplinar.

${ }^{147}$ Ver: CAPOGROSSI COLOGNESI, Luigi; GIARDINA, Andrea; SCHIAVONE, Aldo (ed.). Analisi marxista e società antiche. Roma: Riuniti, 1978; GIARDINA, Andrea. SCHIAVONE, Aldo (ed.). Società romana e produzione schiavistica. Roma; Bari: Laterza, 1981; e GIARDINA, Andrea (ed.) L'Uomo romano. Bari: Laterza, 1989 - na qual se sobressai o excelente capítulo que A. Schiavone dedica aos juristas (p. 81-98). Tradução ao espanhol: GIARDINA, Andrea. El hombre romano. Madrid: Alianza, 1991.

${ }^{148}$ DE MARTINO, Francesco. Storia economica di Roma antica. Firenze: La Nuova Italia, 1979; há tradução: DE MARTINO, Francesco. Historia económica de la Roma antigua. Madrid: Akal, 1985.

${ }^{149}$ Há muitas obras interessantes, tanto individuais quanto coletivas. Talvez, uma das mais recentes e emblemáticas seja: PINA POLO, Francisco; MARCO SIMÓN, Francisco; REMESAL RODRÍGUEZ, José (coord.). Repúblicas y ciudadanos, modelos de participación cívica en el mundo antiguo. Barcelona: Universidad de Barcelona, 2006.

${ }^{150}$ PINA POLO, Francisco. Las contiones civiles y militares en Roma. Zaragoza: Universidad de Zaragoza, 1989.

${ }^{151}$ ROYO ARPÓN, José María. Ciudad abierta. Ciudad de Ciudadanos. Madrid: Marcial Pons, 2001.

${ }^{152}$ MURGA GENER, José Luis. El edificio como unidad en la jurisprudencia romana y en la lex. Sevilla: Servicio de Publicaciones de la Universidad, 1986; MURGA GENER, José Luis; PARICIO, Javier. La denuncia de obra nueva en el Derecho Romano clásico. Barcelona: Bosch, 1982; MURGA GENER, José Luis. Protección a la estética en la legislación urbanística del Alto Imperio. Sevilla: Publicaciones de la Universidad, 1976.
} 
sobre o Direito municipal romano ${ }^{153}$, o qual completou substancialmente a historiografia deste tema.

Sobre o Direito da cidade e da cidadania, ligado à República e ao Império, após os trabalhos de Kunkel ${ }^{154}$ e Nörrr ${ }^{155}$, as obras se multiplicaram em linhas muito diversas, todas elas em ampla conexão com questões de Direito público, administrativo e constitucional. Entre elas, pode-se destacar o estudo da administração provincial ${ }^{156}$ e o Direito eleitoral ${ }^{157}$. Na Espanha, Antonio Fernández de Buján ${ }^{158}$ e seus discípulos trataram de fundar uma nova orientação dos estudos do Direito administrativo romano a partir da ótica das categorias modernas desta disciplina.

Na Espanha, o professor Remesal ${ }^{159}$, em estreita conexão com J. M. Blázques e com outros historiadores da economia romana, como Jean Andreau ${ }^{160}$, matizou muito a história do Direito mercantil, que frequentemente foi esquecida pelos romanistas, centrados exclusivamente no Direito civil e, em pouquíssimos casos, na relação entre o trabalho e o Direito $^{161}$. A obra de Andreau contribuiu muito para o conhecimento das formas de pagamento, dos documentos de pagamento e de depósito etc., que articulavam o mundo comercial romano. Um trabalho recente nesta direção é o de Marta García Morcillo sobre as vendas por leilão ${ }^{162}$. Na Itália, atualmente, há alguns trabalhos interdisciplinares sobre o Direito mercantil e a economia romana dos quais participam historiadores, arqueólogos e

\footnotetext{
153 CAPOGROSSI COLOGNESI, Luigi; GABBA, Emilio (coord.). Gli statuti municipali. Pavia: Ius Press, 2006.

${ }^{154}$ KUNKEL, Wolfgang. Staatsordnung und Staatpraxis der Römischen Republik, 2: Die Magistratur. München: Beck, 1995.

155 NÖRR, Dieter. Imperium und Polis in der Hohen Prinzipatszeit. München: Beck, 1969.

156 SLOOTJES, Daniëlle. The governor and his subjects in the Later Roman Empire. Leiden: Brill, 2006.

${ }^{157}$ RIBAS ALBA, José María. Democracia en Roma. Introducción al Derecho electoral romano. Granada: Comares, 2008; e RAMPAZZO, Natale. Quasi praetor non fuerit. Studi sulle elezioni magistratuali in Roma repubblicana tra regola ed eccezione. Napoli: Satura Editrice, 2008.

${ }^{158}$ FERNÁNDEZ DE BUJÁN, Federico (dir.). Derecho administrativo histórico. Santiago de Compostela: Escola Galega de Administración Pública, 2005.

${ }^{159}$ BLÁZQUEZ MARTÍNEZ, José María; REMESAL, José. Estudios sobre el Monte Testaccio (Roma). v. I-IV. Barcelona: Universitat de Barcelona, 1999-2007.

${ }^{160}$ Entre muitos outros, podem ser citados: ANDREAU, Jean. Les commerçants, l'élite et la politique romaine à la fin de la République (III ${ }^{\mathrm{e}}-\mathrm{I}^{\mathrm{er}}$ siècles av. J.-C.). In.: ZACCAGNINI, Carlo. Mercanti e politica nel mondo antico. Roma: L'Erma di Bretschneider, 2003. p. 217-243; e ANDREAU, Jean. Vie financière dans les deux moitiés de l'Empire romain: remarques comparatives. In: HANTOS, Theodora. Laurea internationalis, Festschrift für Jochen Bleicken zum 75. Geburtstag. Wiesbaden: Franz Steiner, 2003. p. 09-25.

${ }^{161}$ ROBERTIS, Francesco Maria de. Lavoro e lavoratori nel mondo romano. Bari: Adriatica, 1963.

162 GARCÍA MORCILLO, Marta. Las ventas por subasta en el mundo romano: la esfera privada. Barcelona: Universidad de Barcelona, 2005.
} 
juristas, que renovaram parcialmente uma especialidade que os juristas eram pouco propensos a estudar ${ }^{163}$.

Esta visão interdisciplinar aumentou o interesse pelo Direito público e suas relações com a economia e o sistema escravagista e de repressão. Em muitos casos, o interesse relativamente recente pelo Direito penal em Roma nasce de perguntas graças à economia e a sociologia. Os recentes trabalhos em Direito penal romano renovam as perspectivas de Mommsen e de Ferrini graças aos novos problemas. Destacam-se os trabalhos de Luigi Garofalo $^{164}$, Bernardo Santalucia ${ }^{165} \mathrm{e}$, na Espanha, foram lidas várias teses doutorais, dentre as quais pode-se destacar a de Rosario de Castro-Camero ${ }^{166}$ - elaborada a partir do descobrimento de uma em bronze (cópia A) do Senatus-consultum de Cneo Pisone patre (20 d. C.), até agora desconhecido, e que permite corroborar alguns dados de Tácito apresentava e a de J. A. González Romanillos, o qual acabou de publicar um livro que mostra a intersecção do Direito penal com a ciência política e a sociologia ${ }^{167}$.

A influência da interdisciplinaridade marxista permitiu, entre outras coisas, que os canais de comunicação acadêmica entre as diferentes especialidades fossem mais fluidos. Inclusive alguns trabalhos isolados escritos por alguns romanistas já levam o selo interdisciplinar, embora não sejam obras formalmente marxistas. Por exemplo, na Itália, sobressaem-se os recentes trabalhos editados por L. Minieri e O. Sacchi ${ }^{168}$ sobre a tradução do Digesto, assim como o erudito e interdisciplinar trabalho de Lucio de Giovanni, que integra as fontes jurídicas romanas em seu contexto político, social e cultural ${ }^{169}$.

$\mathrm{Na}$ Espanha, destacam-se as obras do professor Alfonso Castro, que soube integrar os textos históricos e literários para esclarecer a realidade do Direito em Roma. Castro entende que a historiografia do Direito Romano não se define unicamente com os textos jurídicos, devendo recorrer a todas as fontes escritas para melhor conhecer o marco cultural, social e

\footnotetext{
163 CERAMI, Pietro; PETRUCCI, Aldo; PORTO, Andrea di. Diritto commerciale romano. Profilo storico. Torino: Giappichielli, 2004; e MIGNONE, Gianni. Un contratto per i mercanti del Mediterraneo. L'evoluzione del rapporto partecipativo. Napoli: Jovane, 2005.

${ }^{164}$ GAROFALO, Luigi. Appunti sul diritto criminale nella Roma monarchica e repubblicana. Padova: CEDAM, 1993; Id., Piccoli scritti di diritto penale romano. Padova: CEDAM, 2008.

${ }^{165}$ SANTALUCIA, Bernardo. Altri studi di diritto penale romano. Padova: CEDAM, 2009.

${ }^{166}$ CASTRO CAMERO, Rosario de. El crimen maiestatis a la luz del senatus consultum de Cn. Pisone Patre. Sevilla: Secretariado de Publicaciones de la Universidad, 2000.

${ }^{167}$ GONZÁLEZ ROMANILLOS, José Antonio. La corrupción política en época de Julio César: un estudio sobre la 'Lex Iulia De Repetundis'. Granada: Comares, 2009.

168 MINIERI, Luciano; SACCHI, Osvaldo (coord.). Problemi della traduzione dei digesti giustinianei nelle lingue europee. Napoli: Jovene, 2007.

${ }^{169}$ GIOVANNI, Lucio de. Istituzioni, scienza giuridica, codici nel mondo tardoantico: Alle radici di una nuova storia. Roma: L'erma di Bretschneider, 2007.
} 
político $^{170}$. Em seu Compêndio, entende que o Direito Romano é o húmus da cultura jurídica europeia, e que o Direito europeu cresce e se desenvolve na Idade Média e na Modernidade condicionado pelos avatares políticos, sociais e culturais - como uma evolução histórica do Direito Romano justinianeu, que permite que se fale em uma projeção sociocultural do Direito Romano até os dias atuais.

Em muitos aspectos, a vocação de Castro parece-se com a que chamei de "históricocultural" ${ }^{\prime 171}$ - ao estilo de Cannata -, e a continuidade histórica poderia situá-lo próximo aos neopandectistas, ainda que sua abertura a problemas teóricos (oralidade e escrita, o status da ciência jurídica...) e sua explicação multidisciplinar o afaste de tal categorização. Castro mostra claramente a evolução do Direito Romano como Direito positivo e como produto cultural, distinguindo ambas as facetas. Pode-se dizer que este autor defende uma história cultural e interdisciplinar do Direito Romano, no qual se entende o Direito como uma manifestação sociocultural e política, que tem amplas conexões com a história literária, social, política e filosófica.

\subsubsection{A corrente antropológico-crítica}

A abertura interdisciplinar dos romanistas os levou, em alguns casos, à consideração antropológica do Direito Romano. Se as diferentes vias da corrente "histórico-contextualista" tentavam aproximar-se do Direito Romano a partir da problematização do contexto do estudo, a visão "antropológico-crítica" não apenas quer interpretar e compreender, mas também relativizar, desmascarar e até desconstruir as bases da Romanística. Estes autores não se conformam com a problematização da compreensão (hermenêutica) ou com o estudo interdisciplinar; querem dar um passo além, crítico-conceitual, de maneira que se reavalie toda a compreensão histórico-ideológica de Roma e do Direito Romano.

Há várias linhas, distintas entre si, mas que podem ser agrupadas em duas seções. A primeira compartilha, em geral, uma visão foucaultiana e tem ramificações nas diferentes posturas deste autor francês. A segunda se dirige mais claramente à Antropologia jurídica,

\footnotetext{
170 CASTRO SÁENZ, Alfonso. Compendio histórico de Derecho Romano: Historia, recepción y fuentes. Madrid: Tebar, 2005.

${ }^{171}$ CASTRO SÁENZ, Alfonso. Un pasado de Europa I: Elementos para una historia de la ciencia jurídica europea - de Roma a nuestros días. Sevilla: El Giraldillo, 2009.
} 
que recupera algumas posturas da Sociologia jurídica e da Romanística do início do século XX para adaptá-las às atuais formulações.

\subsubsection{A visão foucaultiana}

Duas das principais preocupações de Foucault foram a arqueologia e a genealogia do saber e do poder. Este filósofo francês se interessou pela história do Direito e deu lugar a alguns trabalhos histórico-jurídicos. Para a historiografia crítica do Direito Romano, convém distinguir aqui as preocupações mais ontológicas e epistemológicas.

Como é sabido, Foucault explicou que, no Iluminismo e com o Idealismo, o homem havia se colocado fora da história e começado a julgá-la. Esta é, em grande parte, a posição hegeliana. Até aqui, explicou-se, de forma geral, a dialética histórica dos romanistas com Hegel: o filósofo alemão criou alguns conceitos que o positivismo não excluiu por conta da especialização, e quase toda tentativa de voltar ao todo hegeliano se fez de acordo com a via neo-hegeliana dos marxistas.

O marxismo se dedicou a secularizar a história hegeliana, substituindo-a por uma visão materialista. Foucault, discípulo de Nietzsche, tentou escavar os conceitos hegelianos para abrir lacunas na busca de significados e conceitos que haviam sido esquecidos pelo discurso abstrato de Kant que Hegel havia levado às águas da história.

Alguns romanistas marxistas, ao final do século XX e até nossos dias, aproximaram seu discurso à genealogia e à arqueologia. Gostaria de comentar muito brevemente sobre a evolução dos grandes romanistas aos quais fiz alusão quando me referia ao marxismo: Aldo Schiavone e Luigi Capogrossi Colognesi.

Este último autor escreveu recentemente vários livros sob a ideia estrutural do poder em Roma. Pode-se dizer que Capogrossi Colognesi iniciou sua ideia estruturalista cultivando o marxismo: sua obra de juventude mais famosa explicava a estrutura da propriedade na Roma republicana ${ }^{172}$. Nas últimas obras, sem renunciar ao componente social, aprofundou a busca pelas estruturas por meio das quais é produzido o significado dentro da civilização romana.

${ }^{172}$ CAPOGROSSI COLOGNESI, Luigi. La struttura della proprietà e la formazione del "iura pradiorum" nell'età repubblicana. Roma: Giuffrè, 1969-1976. 
Ao longo da primeira década do século XXI, publicou trabalhos sob esta orientação ${ }^{173}$, e, ultimamente, centrou-se no problema do poder ${ }^{174}$. Seu último livro, Storia di Roma tra diritto e potere é uma obra sem notas, destinada a traçar as grandes linhas do significado estrutural de Roma. Seu propósito fica muito patente na contracapa da obra, na qual se pode ler com grande clareza o que o autor defende:

[o] presente volume distingue-se por uma abordagem diferente: ao delinear um quadro essencial, mas não simplificado ou banalizado, da história de um sistema de poder e de governo, fornece não só um resumo informado de como a civilização jurídica moderna foi construída a partir do Direito Romano, mas também oferece um relato histórico não influenciado por categorias típicas da modernidade. A história percorrida pelos romanos, também em termos de organização do Estado e de formação da soberania, foi, de fato, muito acidentada e variada. A respeito desta 'outra' história e dos complexos testemunhos a ela relacionados, o autor se fez intérprete, percorrendo as etapas fundamentais - da República ao Império e ao seu declínio - e captando uma imagem mais próxima da realidade. ${ }^{175}$

Podem-se notar claramente as ideias apontadas sobre a visão foucaultiana: a preocupação pela descrição do "sistema de poder", o afã de escrever sobre Roma sem a influência das categorias da Modernidade (leia-se "Hegel") e, em suma, dar conta da "outra" história.

Aldo Schiavone escreveu nos últimos anos trabalhos romanísticos muito importantes ${ }^{176} \mathrm{e}$, cada vez mais, tem se aproximado do método genealógico foucaultiano. Deve-se dizer que, em sua juventude, Schiavone estudou detidamente a construção do Direito e da Romanística no século XIX, e o fez sob alguns pressupostos claramente arqueológicos ${ }^{177}$.

\footnotetext{
${ }^{173}$ CAPOGROSSI COLOGNESI, Luigi. Persistenza e innovazione nelle strutture territoriali dell'Italia romana. Napoli: Jovene, 2002; CAPOGROSSI COLOGNESI, Luigi. Remissio mercedis. Una storia tra logiche di sistema e autorità della norma. Napoli: Jovene, 2005.

174 CAPOGROSSI COLOGNESI, Luigi. Diritto e potere nella storia di Roma. Napoli: Jovene, 2007; CAPOGROSSI COLOGNESI, Luigi. Dalla storia di Roma alle origini della società civile. Un dibattito ottocentesco. Bologna: Il Mulino, 2008; CAPOGROSSI COLOGNESI, Luigi. Storia di Roma tra diritto e potere. Bologna: Il Mulino, 2009.

${ }^{175}$ CAPOGROSSI COLOGNESI, L. Storia di Roma tra diritto e potere. Bologna: Il Mulino, 2009: "Il presente volume si distingue per un approccio diverso: nel delineare un quadro essenziale, ma non semplificato o banalizzato, della storia di un sistema di potere e di governo fornisce non solo una informata sintesi su come si è venuta costruendo la moderna civiltà giuridica a partire dal diritto romano, ma offre anche un resoconto storico non influenzato da categorie tipiche della modernità. La storia percorsa dai Romani, anche in termini di organizzazione statuale e formazione della sovranità, è stata di fatto molto accidentata e variegata. Di questa 'altra' storia e delle complesse testimonianze ad essa relative l'autore si è latto interprete, ripercorrendone le tappe fondamentali -dalla repubblica all'impero e al suo declino-e cogliendone un'immagine più aderente alla realtà".

${ }^{176}$ SCHIAVONE, Aldo. La storia spezzata. Roma antica e Occidente moderno. Roma; Bari: Laterza e Fili Spa, 1999.

${ }^{177}$ SCHIAVONE, Aldo. Alle origini del diritto borghese: Hegel contro Savigny. Roma; Bari: Laterza, 1984; SCHIAVONE, Aldo. Storiografia e critica del diritto, per una 'archeologia' del diritto privato moderno. Bari: De Donato, 1880.
} 
Em sua última obra, intitulada Ius, recentemente traduzida ao espanhol ${ }^{178}$, Schiavone se mostra decididamente genealógico: consumou uma trajetória seguindo a obra de Foucault. Seu marxismo, também presente, ficou mais depurado que nas obras anteriores. A missão de Ius é estudar o Direito Romano como uma técnica de disciplinamento social. A linguagem é, em si mesma, muito reveladora:

O fluxo de interações entre modelos analíticos e relações de poder que constituía a microfísica daqueles discursos; as estruturas lógicas que estavam em jogo; a trama das técnicas de raciocínio e argumentação que eram elaboradas; as genealogias intelectuais que as haviam implicado e as ligavam à história do próprio saber e às histórias de outras disciplinas antigas (filosofia, retórica, historiografia, medicina); o alcance e o significado das obras às quais aqueles textos haviam permanecido; as convicções acerca do próprio rol e as próprias tarefas nas quais foram reconhecidas por seus autores - e que aqueles documentos ainda permitiram descobrir, ainda que, com frequência, apenas mediante indícios; a rede de interferências entre constituições jurídicas, formas políticas e organização econômica: todo este universo era constantemente ignorado; e com ele, este cenário de problemas que acompanha, em geral, toda investigação, quando se trata de descobrir os movimentos e os percursos de um saber a respeito da constituição e da modificação das relações sociais que atravessam-no e (em parte) o determinam ${ }^{179}$.

Como se pode ver, o método genealógico estrutura claramente os interesses de Schiavone. Na obra, ele explica a evolução do Direito Romano como configuração de um poder e de um saber que se já isolou dos demais. Schiavone, depois de o criticar, escusa parcialmente Schultz em seu trabalho como historiador, pois argumenta que os próprios juristas romanos apagaram suas próprias origens e os rastros anteriores. Estiveram interessados, em um determinado momento, em erigir-se em uma elite que concentrava um poder imenso e que era capaz de criar uma sintaxe jurídica que ordenasse o mundo ${ }^{180}$, de modo que foi necessário desconectar o Direito do passado, que era um ato de vontade, para passar a ser mais técnico, um ato de conhecimento ${ }^{181}$.

Com efeito, Schiavone dá ênfase à necessidade de isolamento do Direito como uma técnica calculadora e disciplinante, e à apresentação do ius como o logos do Direito. $\mathrm{O}$ matrimônio entre o Direito e a filosofia helenística acabou conformando o Direito dos romanos com a linguagem universal da expressão do poder e, com isso, uma ontologização dos conceitos jurídicos ${ }^{182}$.

\footnotetext{
${ }^{178}$ SCHIAVONE, Aldo. Ius. La invención del Derecho en Occidente. Buenos Aires: Adriana Hidalgo, 2009.

179 Ibid., p. 49-50.

${ }^{180}$ Ibid., p. 56-57.

181 Ibid., p. 287.

182 Ibid., p. 222-229.
} 
Esta linha foucaultiana aponta para a importância do estudo da linguagem como expressão de poder. Na Espanha, o romanista José María Royo se dedica ao estudo desta linguagem. A obra do professor Royo se assenta na antropologia linguística do Direito Romano, a qual parte da concepção de Roma como uma sociedade eminentemente agrária. Como tal, a origem etimológica de suas palavras nasce ligada a usos agrícolas, de modo que, por meio dos contrastes entre a pluralidade semântica das diversas palavras que, depois, incorporam o poder, pode ser conjecturada a construção desta linguagem técnica ${ }^{183}$.

Esta linha, de certa maneira, é o revés da história conceitual, pois Royo procura, com isso, uma arqueologia dos significados ocultos de cada uma das palavras que configuraram a linguagem jurídica ocidental. Assim, por exemplo, "manus", "cives", "ius", "civitas", "auctoritas" etc., têm muitos significados deslocados, que ficaram preteridos em favor de outros. Para Royo, tais mudanças terminológicas não correspondem a uma simples evolução da linguagem, mas a uma configuração e a uma transformação produzidas a partir da época imperial.

As contribuições destes historiadores de Roma anteriormente citados não suscitaram, entre os juristas romanistas, excessiva atenção. Contudo, seu labor segue sendo um incentivo para o estudo estrutural e político de Roma, que permite extrair importantes consequências para a historiografia crítica do Direito Romano.

\subsubsection{A corrente da Antropologia jurídica}

A antropologia jurídica foi integrando diferentes correntes do pensamento jurídico e da Romanística que, em geral, foram marginais à história. Sob a denominação "antropologia jurídica", podem ser entendidos métodos muito distintos, embora todos eles levem em conta o que a humanidade tem em comum na hora de regular e de pensar o Direito.

De certa maneira, o que foi dito anteriormente acerca do comparatismo e do Direito, aplica-se aqui de forma bem ampliada: estuda-se o Direito na humanidade como produto social, cultural e até natural. Os cultivadores da Antropologia jurídica podem ter uma visão mais sociológica ou mais naturalista, mas todos coincidem no caráter evolutivo do Direito no marco das sociedades, assim como na presença de elementos comuns em todas elas. Suas

${ }^{183}$ ROYO ARPÓN, José María. Palabras con poder. Madrid: Marcial Pons, 1997. 
contribuições foram solidificando uma historiografia que influenciou mais historiadores que romanistas, ainda que pareça que a situação esteja mudando.

A antropologia jurídica talvez tenha nascido com Fustel de Coulanges, que se interessou em sua juventude pelo Direito em Roma. Sua obra La cité antique ${ }^{184}$ renovou substancialmente a questão da propriedade e das relações político-institucionais e religiosas em Roma. Por sua parte, Henry Sumner Maine ${ }^{185}$ considerou que a sociedade romana experimentou um processo no qual o individual foi substituindo o coletivo familiar como centro de atenção da regulação jurídica. Para Maine, a liberdade individual conduzia às "progressive societies", nas quais a dependência e a submissão ao "paterfamilias" estavam decrescendo.

Maine, como é sabido, estabeleceu as bases da Antropologia jurídica baseada na comparação histórica, uma senda em que os juristas romanistas não seguiram. Mitteis e Wenger, no século XX, a partir da ótica da Romanística germânica, tentaram recuperar uma história comparativa dos Direitos da Antiguidade que, como foi visto antes, não obteve êxito.

Lewis H. Morgan, em Ancient Society ${ }^{186}$, distinguiu três estágios de evolução da humanidade: selvageria, barbárie e civilização. Morgan apostou claramente no evolucionismo, depois compartilhado pelo romanista Pietro Bonfante ${ }^{187}$. Este professor italiano considerou que as instituições de Direito Romano eram organismos vivos, os quais nasceram, desenvolveram-se e extinguiram-se ou sofreram mutação. Esta visão, mais naturalista que sociológica, queria distanciar-se da linha comparatista para mostrar o processo individual de cada uma das civilizações. Para Bonfante, cada instituição jurídica somente poderia ser entendida no contexto da vida social e política de cada um dos povos, de maneira que cada caso deveria ser estudado singularmente.

Esta linha, se houvesse sido cultivada, poderia ter se conectado com o estruturalismo. Entretanto, boa parte da Antropologia jurídica de meados do século XX vinculou-se progressivamente à Antropologia política, sendo difícil separar os trabalhos nessas disciplinas, sobretudo os orientados a partir de uma ótica marxista, tais como os de Balandier.

\footnotetext{
${ }^{184}$ FUSTEL DE COULANGES, Numa Denis. La Cité antique: Étude sur le culte, le droit, les institutions de la Grèce et de Rome. Paris: Durand, 1864.

${ }^{185}$ MAINE, Henry James Sumner. Ancient law: Its connection with the early history of society and its relation to modern ideas. London: John Murray, 1861.

${ }^{186}$ MORGAN, Lewis H. Ancient Society. New York: Holt, 1877.

${ }^{187}$ BONFANTE, Pietro. Il metodo naturalistico nella storia del diritto. In: Scritti giuridici varii. v. IV. Roma: Aracne, 1925. Sobre Bonfante e a Antropologia jurídica: FERLITO, Sergio. Le religioni, il giurista e l'antropologo. Soveria Mannelli (Catanzaro): Rubbettino, 2005.
} 
A antropologia estruturalista do Direito Romano não teve muitos cultivadores, e parece que apenas Christian Meier ${ }^{188}$ fez uma aproximação jurídico-política à sociedade antiga que fosse capaz de integrar as linhas antropológico-históricas e a metodologia foucaultiana.

Em todo caso, atualmente, a Antropologia jurídica parece ter certa força na França. A obra de Norbert Rouland ${ }^{189}$ adquiriu grande notoriedade, pois estuda as sociedades a partir do ponto de vista histórico-comparativo. Rouland, no entanto, sofreu muitas críticas por adotar um prisma demasiadamente etnocentrista, no qual se examina o Direito Romano sem adentrar em sua "genealogia". Na Espanha, há poucos antropólogos e romanistas que se dediquem à Antropologia jurídica do Direito Romano - embora se possa destacar o romanista galego Ramón Rodríguez Montero ${ }^{190}$, interessado igualmente no Direito consuetudinário.

Como crítica à Antropologia jurídica "eurocêntrica" de Rouland, alguns antropólogos e juristas introduziram o argumento multiculturalista e a impugnação imperialista e colonialista do Direito Romano. Esse foi o tema do "XIV Congresso Latino-americano de Direito Romano".

Por fim, o jusprivatista italiano P. G. Monateri ${ }^{191}$ considera que o Direito Romano é uma ficção com um claro propósito ideológico: manter o "não-Ocidental” à margem do Ocidental. Este autor culpa Savigny por ter colocado o Direito Romano como base de uma sociedade capitalista ocidental. Monateri escreve que “o que chamo de 'Direito Romano' é, de fato, um produto multicultural, resultante do esforço de distintas civilizações mediterrâneas, em sua maioria africanas e semitas ${ }^{192}$.

A crítica de Monateri apresenta uma reconsideração crítica da "tradição jurídica" romanística, que, segundo este professor italiano, fincava suas raízes em povos vizinhos. Este argumento permite revisar o conceito de "tradição jurídica" - em um sentido muito diferente da interpretação histórico-cultural e hermenêutica - à luz do Direito comparado dos povos da Antiguidade e da antropologia histórica do Direito, dois campos de estudo em expansão em nossos dias.

\footnotetext{
${ }^{188}$ MEIER, Christian. Introduction à l'anthropologie politique de l'Antiquité classique. Paris: PUF, 1984.

189 ROULAND, Norbert. Anthropologie juridique. Paris: PUF, 1988.

190 Por exemplo: RODRÍGUEZ MONTERO, Ramón P. Usos sociales y regulación jurídica de la capacidad patrimonial de los 'filii familias': puntos de referencia del desarrollo estructural y funcional del 'peculium a patre profectum, castrense' y 'quasi castrense' en Roma. Anuario da Facultade de Dereito da Universidade da Coruña, n. 2, p. 419-430, 1998.

${ }^{191}$ MONATERI, Pier Giuseppe. Black Gaius: A Quest for the Multicultural Origins of the 'Western Legal Tradition'. Hastings Law Journal, v. 51, n. 3, p. 479-564, 2000.

${ }^{192}$ Cito através da tradução ao espanhol: MONATERI, Pier Giuseppe. Gayo, el Negro: una búsqueda de los orígenes multiculturales de la tradición jurídica occidental. In: MONATERI, P. G.; SAMUEL, Geoffrey. La invención del Derecho privado. Bogotá: Siglo del Hombre Editores, 2006.
} 


\subsubsection{A investigação "ad extra": um rápido balanço}

A investigação "ad extra" se ocupa da abertura dos romanistas - individualmente ou em grupos interdisciplinares - às humanidades e às ciências sociais. Enquanto, nestes âmbitos, o desenvolvimento historiográfico foi muito rápido e mutante, na Romanística, as mudanças produziram-se com de forma muito mais lenta.

Todas estas linhas se opõem a uma visão dogmática e estática de Roma e do Direito Romano, seja enfatizando a função do investigador e sua aproximação à realidade, seja por meio de um estudo histórico, social ou linguístico do Direito nos diferentes momentos da civilização romana.

Este grupo de correntes mostra o fecundo diálogo dos romanistas com as ideias e com a metodologia das Humanidades e das ciências sociais, um fato que transformou a historiografia do Direito Romano mediante ensaios fenomenológicos, marxistas, contextualistas, foucaultianos, linguísticos etc. do Direito Romano. Todos estes métodos e sua tradução historiográfica do Direito Romano acabaram superando a historiografia do século XIX, que havia compartimentado o saber. Graças a este frutífero diálogo, puderam ser superadas as barreiras do positivismo histórico e das categorias hegelianas.

\section{CONCLUSÕES}

Ao longo deste trabalho, foram examinados alguns caminhos que foram empreendidos pelos romanistas depois da codificação do BGB. Os antecedentes, explicados resumidamente, tentavam mostrar o posicionamento de Hegel, Savigny, Ranke e Mommsen frente ao Direito Romano e sua relação com as demais esferas do saber.

Assim como a historiografia do século XX sofreu uma grande tensão dialética com os pressupostos de Ranke, os estudos sobre Roma também foram sendo construídos e reconstruídos sobre a base de Mommsen. Se a configuração categorial de Hegel e sua história do espírito universal foram escanteadas pela historiografia filosófica do século XX, ainda deve-se saber, para concluir, qual é o legado na Romanística atual. Por último, é cabido extrair algumas conclusões acerca de qual é o posicionamento historiográfico a respeito de Savigny. 
Com efeito, na via "ad intra", poucos são os que reclamaram diretamente uma "volta a Savigny"; a direção empreendida é, antes, uma metamorfose em direção ao Direito Romano como húmus do saber jurídico europeu. Os neopandectistas parecem ter se transformado em historiadores do Direito privado da Europa e encontraram no Direito comunitário uma tábua de salvação para a construção de um novo Direito no qual pudessem integrar alguns "princípios" da Romanística.

Entretanto, o peso historiográfico desta corrente está destinado a ser cada vez menor, pois seus estudos não buscam tanto a compreensão do passado quanto a adequação destes princípios atemporais ao futuro. Creio que a via comparatista acabará, com o tempo, limitando o legado de Savigny, e a busca de um Direito comum, universal ou global terá que convergir a uma visão histórica ou terá que fazer grandes concessões para buscar uma positivação muito mais abrangente.

Este caminho neopandectista, a partir do ponto de vista da historiografia do Direito Romano, não representa nenhuma contradição com os outros estudos romanísticos, pois serão cada vez menos as considerações historiográficas que venha lançar. Existirá, portanto, um divórcio entre os romanistas dogmáticos do Direito, que se dedicaram a aconselhar e a traçar realidades jurídicas que pouco tem a ver com o Direito de Roma, e os que o estudam historicamente.

Gostaria de ver na obra de Coing e Zimmermann um espírito crítico quanto às categorias, ou, ao menos, um distanciamento efetivo do passado. Com sua contribuição, estão sendo postas as bases supostamente romanísticas de um Direito artificial, como o europeu, que se traduzirá nas obras que estabelecerão as bases do Direito positivo sem alterar as vias do conhecimento historiográfico da civilização romana.

Savigny disse que protegia o Direito histórico e construiu uma síntese racional de Direito Romano. Do mesmo modo procedem os neopandectistas, argumentando que estão construindo o Direito europeu por meio do Direito Romano. Seu labor é a elaboração de um Direito privado europeu, e sua atividade supõe um trabalho de argumentação que necessita de certa roupagem histórica.

Contudo, o caminho dos neopandectistas é uma senda juspositivista e pragmática. Os trabalhos de Zimmermann são muito elaborados e têm uma grande vocação argumentativa, mas tanto ele como os continuadores da senda sabem que não cultivam o Direito Romano, apenas o tomam como pretexto para adornar um edifício que necessita de uma "auctoritas", já que ele não goza de suficiente "potestas" democrática. 
Os que cultivam a história conceitual se dedicam, em última instância, a explicar o Direito positivo atual, atendendo às metamorfoses existentes. Se este labor se faz separando o que é Direito Romano do que é Direito civil vigente, é uma senda sumamente interessante, que pode, inclusive, distanciar-se muito das sínteses abstratas como a de Schultz, e que pode dar frutos na historiografia do Direito civil.

$\mathrm{Na}$ corrente neo-humanista, os que se dedicam ao estudo histórico-filológico têm, atualmente, as portas abertas para trabalhar em pé de igualdade com filólogos, arqueólogos e historiadores, de modo que o dogma oitocentista que separava as áreas de estudo ruiu, sendo isso fruto dos avanços historiográficos produzidos graças à pluralidade metodológica e à interdisciplinaridade.

A aproximação histórico-cultural também requer um trabalho com as mesmas características, de modo que a investigação "ad intra" não pode gerar grandes frutos no futuro se não trabalhar com os demais especialistas. A mera atividade de legitimação do sistema já não é suficiente, e a especialização oitocentista não têm consistência. Portanto, se não quer dedicar-se à dogmática jusprivatista, o estudo do Direito Romano deve passar pelo trabalho interdisciplinar e crítico.

De fato, já são muitos os romanistas que reconheceram a importância do estudo interdisciplinar, o que se traduz e se seguirá traduzindo em grandes avanços historiográficos. Ainda assim, pouquíssimos romanistas seguem mantendo que o Direito Romano, aos dias de hoje, é um Direito vigente; e isso ajuda a separar as vias da dogmática romanística (transformada em um conjunto de materiais de Direito privado, que serve para "orientar" os civilistas e os comercialistas) daquela da visão histórico-filológica (que deve confluir, necessariamente, as demais áreas extrajurídicas afins).

As correntes "ad extra" surgem da pergunta que se faz o romanista sobre seu próprio status. Se, frente à crise, alguns procuram a senda da dogmática e da positividade jurídica, todos os demais devem legitimar seu labor de outra maneira. Em geral, todos os que buscam a senda não-dogmática acabam cultivando a história e, neste sentido, o único interesse histórico do Direito Romano é o puro prazer do conhecimento.

Como o conhecimento pode chegar a transformar as pessoas, a fenomenologia foi o caminho mediante o qual os romanistas começaram a pensar sua própria identidade. Foi daí que se pensou criticamente a ideia de tradição, não como uma forma cultural da Europa, mas como uma forma de mostrar a identidade individual e coletiva. $\mathrm{O}$ reconhecimento das tradições implica a necessidade de explicar as diferenças culturais e, também, a abertura ao 
comparatismo jurídico, não só entre Direitos europeus, mas também em Direitos antigos e modernos, vigentes e não vigentes.

Se o Direito era uma manifestação social e cultural, o que se deu em Roma deveria corresponder também a estas relações. Por isso, o estudo contextualista deveria abarcar uma crescente interdisciplinaridade, a qual obrigara os estudiosos a esquecer as falsas barreiras que existiam entre a filologia, a história, a filosofia, o Direito... O marxismo, por meio de sua raiz hegeliana, aspirava, também, a fornecer uma visão da totalidade. Contudo, o marxismo era, também, uma vacina anti-idealista que ajudava a compreender o Direito como um produto social, cultural e econômico.

A superação definitiva de Savigny e de Hegel viria, ainda, pela via da crítica antropológica, que buscava uma arqueologia conceitual e um desmascaramento da visão totalizante de Roma, a partir de um método linguístico-conceitual, histórico e comparatista. Ao reduzir a história de Roma à evolução de um povo mediterrâneo, similar a muitos outros, com os quais interagia, pode-se entender a gênese e a evolução do Direito. Frente à construção histórica e abstrata do Direito Romano, o estudo antropológico-crítico permite entender o Direito como um produto vivo, desmistificado, e ainda ajuda a entender os interesses que fizeram o Direito Romano um produto "perfeito".

Em suma, não há dúvida de que a pluralidade de métodos é algo muito benéfico. Entretanto, deve-se dizer, também, que todos eles devem dialogar para que existam intercâmbios frutíferos de pontos de vista e para que eles se reflitam na historiografia. O mais importante é que se atue com um sentido crítico, não assumindo dogmas nem précompreensões do passado, examinando rigorosamente o trabalho dos demais e revisando o pensamento próprio à luz dos comentários alheios.

Segundo se pode ver ao longo das páginas precedentes, muitos autores não podem ser classificados em uma tendência, porque: ou aceitaram a pluralidade de métodos, ou foram gestando uma evolução metodológica ao compasso das novas tendências da historiografia. De fato, isso mostra como, a pouco e pouco, foram desmoronando muitas das amarras do século XIX. Neste trabalho, tentei fazer referência aos métodos e às obras clássicas da historiografia, enfatizando as transformações operadas ao longo dos últimos anos. Procurei mostrar, também, que a Romanística atual não só é escrita pelos romanistas, mas que se trabalha em diálogo com os diferentes especialistas.

Se a Romanística "ad intra" foi e é eminentemente de orientação alemã, a panorâmica "ad extra" foi gestada principalmente na Itália. Resulta natural que custe mais aos romanistas 
germânicos romper suas ligações com sua própria tradição e que sua visão sistemática do Direito Romano mantenha seu interesse no Direito privado europeu. Na Itália, operou-se uma maior transformação, posto que o ponto de partida era muito menos dogmático. Também em outros países, como Estados Unidos, França e Inglaterra, o Direito Romano resulta do interesse em estudar a herança cultural europeia, sem margem apenas para a dogmática. $\mathrm{Na}$ Espanha, parece que, a pouco e pouco, as tendências historicistas e interdisciplinares italianas vão ganhando terreno na dogmática.

As obras de tantos romanistas europeus geraram uma profunda mudança historiográfica frente à Romanística dos anos setenta e - digamos até - frente àquela dos anos cinquenta, tal qual tentamos mostrar resumidamente. Na Espanha, também, foram seguidas estas linhas e foram frutíferos os intentos críticos e renovadores. Trata-se, por fim, de importantes mudanças na Romanística, que, ano após ano, modifica seus conhecimentos históricos e que parece ter superado definitivamente as amarras ao século XIX. As atuais tendências historiográficas - quiçá aqui examinadas de forma mais detida por meio de algumas novidades bibliográficas - mostram uma variedade de caminhos que permitem prenunciar um fecundo diálogo com o futuro, que seguirá enriquecendo os estudos romanísticos.

\section{REFERÊNCIAS}

ALBANESE, Bernardo. Premesse allo studio del diritto romano. Palermo: Università di Palermo, 1978.

ALFÖLDY, Géza. Historia Social de Roma. Madrid: Alianza, 1987.

ÁLVAREZ SUÁREZ, Ursicino. Instituciones de Derecho romano I. Madrid: Dykinson, 1978.

ANDREAU, Jean. Les commerçants, l'élite et la politique romaine à la fin de la République (III ${ }^{\mathrm{e}}-\mathrm{I}^{\mathrm{er}}$ siècles av. J.-C.). In.: ZACCAGNINI, Carlo. Mercanti e politica nel mondo antico. Roma: L'Erma di Bretschneider, 2003. p. 217-243.

ANDREAU, Jean. Vie financière dans les deux moitiés de l'Empire romain: remarques comparatives. In: HANTOS, Theodora. Laurea internationalis, Festschrift für Jochen Bleicken zum 75. Geburtstag. Wiesbaden: Franz Steiner, 2003. p. 09-25.

ANDRÉS SANTOS, Francisco Javier. Algunos problemas de traducción de la terminología jurídica romana en el Imperio Bizantino. Minerva: Revista de filología clásica, n. 19, p. 285296, 2006. 
ANDRÉS SANTOS, Francisco Javier. El ambiguo historicismo de Savigny. Seminarios complutenses de Derecho romano - Revista Complutense de Derecho Romano y tradición romanística, n. 19, p. 365-381, 2006.

ANDRÉS SANTOS, Francisco Javier; SIGNES CODOÑER, Juan. La introducción al Derecho (Eisagoge) del Patriarca Focio. Madrid: CSIC, 2007.

ARANGIO-RUIZ, Vincenzo. Historia del Derecho romano. Madrid: Reus, 1943.

ARANGIO-RUIZ, Vincenzo. Storia del diritto romano. Napoli: Jovene, 1931.

ARIAS RAMOS, José. Derecho público romano e historia de las fuentes. Valladolid: Ceres, 1979.

BARCELLONA, Pietro; COTTURRI, Giuseppe. Stato e giuristi tra crisi e riforma. Bari: De Donato, 1974.

BARTOSEK, Milan. Come si dovrebbe studiare attualmente il diritto romano. Alcune idee. In: Studi in onore di Vincenzo Arangio-Ruiz. Napoli: Jovene, 1953.

BARTOSEK, Milan. Metodo tradizionale e materialismo storico nella metodologia del diritto romano. In.: Atti del I Congresso Internazionale della Società Italiana di Storia del Diritto. La storia del diritto nel quadro delle scienze storiche. Firenze: Olschki, 1966. p. 95 et seq.

BERMEJO BARRERA, José. Carlos. Introducción a la historia teórica. Tres Cantos: Akal, 2009.

BERMEJO BARRERA, José. Carlos; PIEDRAS MONROY, Pedro Andrés. Genealogía de la historia: Ensayos de historia teórica. Madrid: Akal, 1999. p. 80-88.

BETANCOURT SERNA, Fernando. Líneas de investigación romanística. Estado de la cuestión. In: BRAVO, Ramón Herrera; REVUELTA, María Salazar. Problemática del Derecho Romano ante la implantación de los nuevos planes de estudio. Jaén: Universidad de Jaén, 1999, p. 77-86.

BETTI, Emilio. Esercitazione romanistiche su casi practici: I, Anormalità del negozio giuridico. Pádua: CEDAM, 1930.

BETTI, Emilio. Il concetto della obbligazione costruito dal punto di vista dell'azione. Pavia: Tip. Cooperativa, 1920.

BETTI, Emilio. La restaurazione Sullana e il suo esito (Contributo allo studio della crisi della costituzione repubblicana in Roma). Pavia: Mattei \& C, 1915.

BETTI, Emilio. La struttura dell'obbligazione romana e il problema della sua genesi.

Milano: Giuffrè, 1919. 
BETTI, Emilio. Storia e dogmatica del diritto. In.: I Congresso Internazionale della Società Italiana di Storia del Diritto. La storia del diritto nel quadro delle scienze storiche. Atti del primo Congresso internazionale. Firenze: Leo S. Olschki, 1966. p. 106 et seq.

BETTI, Emilio. Trattato dei limiti soggettivi della cosa giudicata in Diritto romano. Macerata: Tip. Bianchini, 1922.

BLÁZQUEZ MARTÍNEZ, José María; REMESAL, José. Estudios sobre el Monte Testaccio (Roma). v. I-IV. Barcelona: Universitat de Barcelona, 1999-2007.

BÖCKENFÖRDE, Ernst-Wolfgang. Die Historische Schule und das Problem der Geschichtlichkeit des Rechts. In: BÖCKENFÖRDE, E. Staat, Gesellschaft, Freiheit: Studien zur Staatstheorie und zum Verfassungsrecht. Frankfurt am Main: Suhrkamp, 1976. p. 20 et seq.

BONFANTE, Pietro. Il metodo naturalistico nella storia del diritto. In.: Scritti giuridici varii. Vol. IV, Roma: Aracne, 1925.

BRAVO, Gonzalo. Poder político y desarrollo social en la Roma antigua. Madrid: Taurus, 1989.

BRETONE, Mario. Derecho y tiempo en la tradición europea. Cidade do México: Fondo de Cultura Económica, 2001.

BRETONE, Mario. Diritto e tempo nella tradizione europea. Bari: Laterza, 1999.

BRETONE, Mario. La coscienza ironica della Romanistica. Labeo, Napoli, n. 43, p. 187-201, 1997.

BRETONE, Mario. Postulati e aporie nella History di Schultz. In: AAVV. La giurisprudenza romana nella storiografia contemporanea. Bari: Cacucci, 1982.

BRETONE, Mario. Tecniche e ideologie dei giuristi romani. Napoli: Edizioni Scientifiche Italiane, 1982.

BURDESE, Alberto. Manual de Derecho público romano. Barcelona: Bosch, 1972.

BURDESE, Alberto. Manuale di diritto pubblico romano. Torino: Utet, 1997.

BURGUIÈRE, André. Diccionario de ciencias históricas. Madrid: Akal, 1991.

BURGUIÈRE, André. La escuela de los Annales: Una historia intelectual. Valencia: Universidad de Valencia, 2009.

CAENEGEM, Raoul Charles van. European Law in the Past and the Future. Cambridge: University Press, 2002.

CAENEGEM, Raoul Charles van. Pasado y futuro del Derecho europeo: dos milenios de unidad y diversidad. Madrid: Civitas, 2003. 
CALONGE, Alfredo. La compraventa civil de cosa futura (desde Roma a la doctrina europea actual). Salamanca: Núñez, 1963.

CANNATA, Carlo Augusto. Materiali per un corso di fondamenti del diritto europeo. $2 \mathrm{v}$. Torino: Giappichelli, 2005-2008.

CANNATA, Carlo Augusto. GAMBARO, Antonio. Lineamenti di storia della giurisprudenza europea. La giurisprudenza romana e il passaggio dall'Antichità al Medioevo. v. I. Torino: Giappichelli, 1976.

CANNATA, Carlo Augusto; GAMBARO, Antonio. Lineamenti di storia della giurisprudenza europea. II. Dal Medioevo all'epoca moderna. v. II. Torino: Giappichelli, 1989.

CANNATA, C.; GAMBARO, Antonio. Lineamenti di storia della giurisprudenza europea: II. Dal Medioevo all'epoca moderna. Torino: Giappichelli, 1989.

CANNATA, Carlo Augusto. Lineamenti di storia della giurisprudenza europea: I. La giurisprudenza romana e il passaggio dall'antichità al Medioevo. Torino: Giappichelli, 1976.

CANNATA, Carlo Augusto. Materiali per un corso di fondamenti del diritto europeo. $2 \mathrm{v}$. Torino: Giappichelli, 2005, 2008.

CAPOGROSSI COLOGNESI, Luigi. Dalla storia di Roma alle origini della società civile. Un dibattito ottocentesco. Bologna: Il Mulino, 2008.

CAPOGROSSI COLOGNESI, Luigi. Diritto e potere nella storia di Roma. Napoli: Jovene, 2007.

CAPOGROSSI COLOGNESI, Luigi. La struttura della proprietà e la formazione del "iura prcediorum” nell'età repubblicana. Roma: Giuffrè, 1969-1976.

CAPOGROSSI COLOGNESI, Luigi. Persistenza e innovazione nelle strutture territoriali dell'Italia romana. Napoli: Jovene, 2002.

CAPOGROSSI COLOGNESI, Luigi. Remissio mercedis. Una storia tra logiche di sistema e autorità della norma. Napoli: Jovene, 2005.

CAPOGROSSI COLOGNESI, Luigi. Storia di Roma tra diritto e potere. Bologna: Il Mulino, 2009.

CAPOGROSSI COLOGNESI, Luigi; GABBA, Emilio (coord.). Gli statuti municipali. Pavia: Ius Press, 2006.

CAPOGROSSI COLOGNESI, Luigi; GIARDINA, Andrea; SCHIAVONE, Aldo (ed.). Analisi marxista e società antiche. Roma: Riuniti, 1978. 
CARANDINI, Andrea. Remo e Romolo. Dai rionni dei Quiriti alla città dei Romani (775/750700/675 a. C. circa). Torino: Einaudi, 2006.

CARONI, Pio. La soledad del historiador del Derecho. Apuntes sobre la conveniencia de una disciplina diferente. Madrid: Universidad Carlos III de Madrid, 2010.

CARONI, Pio; DILCHER, Gerhard (ed.). Norm und Tradition. Köln; Weimar; Wien: Böhlau, 1998.

CASINOS MORA, Francisco Javier. Nueve siglos de romanismo jurídico. Rivista di Diritto Romano, v. II, p. 351-399, 2002.

CASTRO CAMERO, Rosario de. El crimen maiestatis a la luz del senatus consultum de Cn. Pisone Patre. Sevilla: Secretariado de Publicaciones de la Universidad, 2000.

CASTRO CAMERO, Rosario. de. Consideraciones en torno a la docencia y a la investigación romanísticas en el marco del Espacio Europeo de Educación Superior: II. Investigación. Annaeus: Anales de la tradición romanística, Sevilla, vol. 2, p. 580, 2005.

CASTRO SÁENZ, Alfonso. Compendio histórico de Derecho Romano: Historia, recepción y fuentes. Madrid: Tebar, 2005.

CASTRO SÁENZ, Alfonso. Panorámica romanística, una aproximación a las corrientes recientes de la investigación. Crónica jurídica hispalense - Revista de la Facultad de Derecho, n. 7, p. 349-411, 2009.

CASTRO SÁENZ, Alfonso. Un pasado de Europa I: Elementos para una historia de la ciencia jurídica europea - de Roma a nuestros días. Sevilla: El Giraldillo, 2009.

CATALANO, Pierangelo. Diritto e persone. Studi su origine e attualità del sistema romano. Torino: Giappichelli, 1990.

CATALANO, Pierangelo. Sistemas jurídicos: Sistema jurídico latinoamericano y Derecho Romano. Revista de Legislación y Jurisprudencia, III, p. 161-178, 1982.

CAVANNA, Adriano. Storia del diritto moderno in Europa: Le fonti e il pensiero giuridico. Milano: Giuffrè, 1982.

CERAMI, Pietro; PETRUCCI, Aldo; PORTO, Andrea di. Diritto commerciale romano. Profilo storico. Torino: Giappichielli, 2004.

CHURRUCA, Juan de; MENTXACA, Rosa. Introducción Histórica al Derecho Romano. Bilbao: Universidad de Deusto, 1987.

COING, Helmut. Europäisches Privatrecht 1500-1800. München: C. H. Beck, 1985.

COING, Helmut. Europäisches Privatrecht 1800-1914. München: C. H. Beck, 1989. 
COING, Helmut. Historia del Derecho privado europeo. Madrid: Fundación Cultural del Notariado, 1996.

COMA FORT, J. M. Índice comentado de las colecciones de fuentes del Corpus Iuris Civilis. Cizur Menor: Thompson-Aranzadi, 2008.

CONTRERAS PELÁEZ, Francisco José. La filosofía de la historia de Johann G. Herder. Sevilla: Universidad de Sevilla, 2004.

CONTRERAS PELÁEZ, Francisco José. La idea de espíritu del pueblo en F. C. V. Savigny. Anales de la Cátedra Francisco Suárez, n. 35, p. 161-187, 2001.

CONTRERAS PELÁEZ, Francisco José. Savigny y el Historicismo Jurídico. Madrid: Tecnos, 2004.

CRIFÒ, Giuliano. Emilio Betti y la cultura jurídica. A propósito de la edición chilena de la interpretación jurídica. Revista Chilena de Derecho, v. 34, n. 1, p. 163-179, 2007.

CRIFÒ, Giuliano. Il compito del romanista. Revista internacional de Derecho romano, p. 0142, 2008.

CRIFÒ, Giuliano. Pandettisti e storicisti nel Diritto romano oggi en Diritto Romano attuale. Storia, Metodo, Cultura nella Scienza Giuridica, n. 1, p. 23-28, 1999.

CUENA BOY, Francisco. Sistema jurídico y Derecho romano. La idea de sistema jurídico y su proyección en la experiencia jurídica romana. Santander: Universidad de Cantabria, 1998.

D’ORS, Álvaro (ed.). El Digesto de Justiniano. 3 v. Cizur Menor: Aranzadi, 1975.

D’ORS, Álvaro. El Código de Eurico. Edición y palingenesia. Madrid; Roma: Boletín Oficial del Estado, 1960.

D’ORS, Álvaro. Epigrafía jurídica de la España romana. Madrid: Instituto Nacional de Estudios Jurídicos, 1953.

D’ORS, Álvaro. Sobre el valor formativo del Derecho romano. In.: D’ORS, Álvaro. Papeles del oficio universitario. Madrid: Rialp, 1961. p. 164 et seq.

DE MARTINO, Francesco. Historia económica de la Roma antigua. Madrid: Akal, 1985.

DE MARTINO, Francesco. Storia della Costituzione romana. Napoli: Jovene, 1973.

DE MARTINO, Francesco. Storia economica di Roma antica. Firenze: La Nuova Italia, 1979.

DOMINGO, Rafael (coord.). Principios de Derecho global: 1000 reglas jurídicas y aforismos comentados. Navarra: Thompson Reuters Aranzadi, 2006.

DOMINGO, Rafael. ¿Qué es el Derecho global? Navarra: Thompson Reuters Aranzadi, 2008 . 
DOMINGO, Rafael. Código civil japonés. Estudio preliminar, traducción y notas. Madrid: Marcial Pons, 2000.

DOMINGO, Rafael. Juristas universales. 4 v. Madrid: Marcial Pons, 2004.

DOMINGO, Rafael. The New Global Law. Cambridge: Cambridge University Press, 2010.

DUPLÁ ANSUÁTEGUI, Antonio. La 'Constitución Romana' como mecanismo de inclusión y exclusión. Studia historica. Historia antigua, n. 26, p. 21-38, 2008.

DUPLÁ ANSUÁTEGUI, Antonio. Notas a propósito de la historiografía neomarxista italiana sobre el mundo clásico. Studia historica. Historia antigua, n. 19, p. 115-142, 2001.

FERLITO, Sergio. Le religioni, il giurista e l"antropologo. Soveria Mannelli (Catanzaro): Rubbettino, 2005.

FERNÁNDEZ BARREIRO, Alejandrino. El factor jurisprudencial como elemento de identidad de la cultura jurídica europea: proyección histórica de la herencia jurídico-cultural romana. Granada: Comares, 1998.

FERNÁNDEZ BARREIRO, Alejandrino. La tradición romanística en la cultura jurídica europea. Madrid: CEURA, 1992.

FERNÁNDEZ BARREIRO, Alejandrino; PARICIO, Javier. Historia del Derecho romano y su recepción europea. $4^{\mathrm{a}} \mathrm{ed}$. Madrid: CEURA, 2000.

FERNÁNDEZ DE BUJÁN, Federico (dir.). Derecho administrativo histórico. Santiago de Compostela: Escola Galega de Administración Pública, 2005.

FERNÁNDEZ DE BUJÁN, Federico. Aportación del Derecho romano al proceso de elaboración del Derecho de la Unión Europea. In: Libro homenaje a Jesús López Medel. t. II. Madrid: Centro de Estudios Registrales: 1999. p. 1757-1772.

FERNÁNDEZ DE BUJÁN, Federico. Contribución del Derecho romano en la futura elaboración de un Thesaurus jurídico europeo. In: Actas de las IV Jornadas de Derecho e Informática. Madrid, 1991. p. 217-223.

FERNÁNDEZ DE BUJÁN, Federico; GARCÍA GARRIDO, Manuel Jesús. Fundamentos clásicos de la democracia y la administración. Madrid: Ed. Académicas, 2010.

FERRINI, Contardo. Diritto penale romano. Teorie generali. Milano: Hoepli, 1899.

FIKENTSCHER, Wolfgang. La concepción de la Historia y del Sistema de Savigny. Anales de la Cátedra Francisco Suárez, n. 18-19, p. 64, 1978-1979.

FOUCAULT, Michel. De lenguaje y literatura. Barcelona: Paidós ICB/UAB, 1996.

FRANCISCI, Pietro de. Sintesi storica del diritto romano. Roma: Bulzoni, 1968. 
FRANCISCI, Pietro de. Síntesis histórica del Derecho romano. Madrid: Editorial Revista de Derecho Privado, 1954.

FRANCISCI, Pietro de. Storia del diritto romano. Milano: Giuffré, 1940-1941.

FUENTESECA DÍAZ, Pablo. Observaciones sobre el futuro del Derecho romano en España. In: Estudios en homenaje al Profesor Francisco Hernández-Tejero. v. II. Madrid:

Universidad Complutense, 1994. p. 205-219.

FUSTEL DE COULANGES, Numa Denis. La Cité antique: étude sur le culte, le droit, les institutions de la Grèce et de Rome. Paris: Durand, 1864.

GARCÍA GARRIDO, Manuel Jesús. El Derecho romano y la historiografía jurídica del siglo XIX. Boletín de la Facultad de Derecho de la UNED, n. 14, p. 75-92, 1999.

GARCÍA GONZÁLES, José María; RASCÓN GARCÍA, César. Ley de las XII tablas. Madrid: Tecnos, 1993.

GARCÍA MORCILLO, Marta. Las ventas por subasta en el mundo romano: la esfera privada. Barcelona: Universidad de Barcelona, 2005.

GAROFALO, Luigi. Appunti sul diritto criminale nella Roma monarchica e repubblicana. Padova: CEDAM, 1993.

GAROFALO, Luigi. La persecuzione dello stellionato in diritto romano. Padova: CEDAM, 1998.

GAROFALO, Luigi. Piccoli scritti di diritto penale romano. Padova: CEDAM, 2008.

GIARDINA, Andrea (ed.) L’Uomo romano. Bari: Laterza, 1989.

GIARDINA, Andrea. El hombre romano. Madrid: Alianza, 1991.

GIARDINA, Andrea. SCHIAVONE, Aldo (ed.). Società romana e produzione schiavistica. Roma; Bari: Laterza, 1981.

GIOVANNI, Lucio de. Istituzioni, scienza giuridica, codici nel mondo tardoantico: Alle radici di una nuova storia. Roma: L'erma di Bretschneider, 2007.

GONZÁLEZ ROMANILLOS, José Antonio. La corrupción política en época de Julio César: un estudio sobre la 'Lex Iulia De Repetundis'. Granada: Comares, 2009.

GORDLEY, James; JIANG; Hao; MEHREN, Arthur Taylor von. An Introduction to the Comparative Study of Private Law. Cambridge: Cambridge University Press, 2006.

GUZMÁN BRITO, Alejandro. Historia de la interpretación de las normas en el Derecho romano. Santiago: Instituto Juan de Solórzano y Pereira, 2000. 
GUZMÁN BRITO, Alejandro. La codificación civil en Iberoamérica. Siglos XIX y XX. Santiago de Chile: Editorial Jurídica de Chile, 2000.

GUZMÁN BRITO, Alejandro. La fijación del Derecho. Contribución al estudio de su concepto y de sus clases y condiciones. Valparaíso: Ediciones Universitarias de Valparaíso, 1977.

GUZMÁN BRITO, Alejandro. Las cosas incorporales en la doctrina y el Derecho positivo. Santiago: Editorial Jurídica de Chile, 1995.

GUZMÁN BRITO, Alejandro. Ratio scripta. Frankfurt am Main: Vitorio Klostermann, 1981.

HAMZA, Gábor. Entstehung und Entwicklung der modernen Privatrechtsordnungen und die römischrechtliche Tradition. Budapest: Eötvös Universitätsverlag, 2009.

HEGEL, George Wilhelm Friedrich. Lecciones sobre filosofía de la historia universal.

Madrid: Alianza, 1974.

HERNÁNDEZ-TEJERO JORGE, Francisco. El latín y los juristas. In: ESTEVE, Jaime Roset. Estudios en homenaje al Profesor Juan Iglesias. Madrid: Universidad Complutense, 1988. p. 353-358.

KASER, Max. Römische Rechtsquellen und angewandte Juristenmethode: Ausgewählte, zum Teil grundlegend erneuerte Abhandlungen. Wien; Köln; Graz: Böhlau, 1986.

KOSCHAKER, Paul. Europa und das römische Recht. München: Biederstein, 1947.

KOSCHAKER, Paul. Europa y el Derecho romano. Madrid: Editorial Revista de Derecho Privado, 1955.

KOSELLECK, Reinhart (ed.). Historische Semantik und Begriffsgeschichte. Stuttgart: KlettCotta, 1979.

KOVALIOV, Sergei Ivanovich. Historia de Roma. Madrid: Akal, 1979.

KUNKEL, Wolfgang. Historia del Derecho romano. Barcelona: Ariel, 2003.

KUNKEL, Wolfgang. Staatsordnung und Staatpraxis der Römischen Republik, 2: Die Magistratur. München: Beck, 1995.

KUNKEL, Wolfgang. Römische Rechtsgeschichte. Köln; Wien: várias edições.

LATORRE, Ángel. Valor actual del Derecho romano. Barcelona: Diresa, 1979.

LEVI, Adolfo. Historia de la filosofía romana. Buenos Aires: Eudeba, 1979.

LEVI, Adolfo. Storia della filosofia romana. Firenze: Sansoni, 1949. 
LÓPEZ BARJA DE QUIROGA, Pedro Manuel. Imperio legítimo. El pensamiento político en tiempos de Cicerón. Madrid: Mínimo Tránsito, 2007.

LÓPEZ BARJA DE QUIROGA, Pedro Manuel. Los partidos políticos en la obra de Mommsen. In: MARTÍNEZ-PINNA, Jorge (coord.). En el centenario de Theodor Mommsen (1817-1903): homenaje desde la Universidad española. Málaga: Universidad de Málaga, 2005. p. 207-218.

LUCHETTI, Giovanni; PETRUCCI, Aldo (ed.). Fondamenti di diritto contrattuale europeo. Dalle radici romane al progetto dei PECL della Commissione Lando. Bologna: Pàtron, 2006.

MAGANZANI, Lauretta. Formazione e vicende di un'opera illustre. Il corpus iuris nella cultura del giurista europeo. Torino: Giappichelli, 2002.

MAINE, Henry James Sumner. Ancient law. Its connection with the early history of society and its relation to modern ideas. Londres: John Murray, 1861.

MALAVÉ OSUNA, Belén. Mommsen y la ciencia del Derecho público. In: MARTÍNEZPINNA, Jorge (coord.). En el centenario de Theodor Mommsen (1817-1903): homenaje desde la Universidad española. Málaga: Universidad de Málaga, 2005. p. 171-178.

MARGADANT, Guillermo F. Introducción a la Historia Universal del Derecho. t. I. Xalapa: Universidad Veracruzana, 1974.

MARGADANT, Guillermo F. Panorama de la historia universal del Derecho: La segunda vida del Derecho romano. México: Porrúa, 1986.

MAS, Salvador. Pensamiento romano: una historia de la filosofía en Roma. Valencia: Tirant lo Blanch, 2006.

MEIER, Christian. Introduction à l'anthropologie politique de l'Antiquité classique. Paris: PUF, 1984.

MERRYMAN, John Henry. La tradición jurídica romano-canónica. México: Fondo de Cultura Económica, 1989.

MIGNONE, Gianni. Un contratto per i mercanti del Mediterraneo. L'evoluzione del rapporto partecipativo. Napoli: Jovane, 2005.

MINIERI, Luciano; SACCHI, Osvaldo (coord.). Problemi della traduzione dei digesti giustinianei nelle lingue europee. Napoli: Jovene, 2007.

MIQUEL, Joan. Historia del Derecho romano. Barcelona: PPU, 1988.

MIQUEL, Joan. Mechanische Fehler in der Digestenüberlieferung. Zeitschrift der Savigny Stiftung für Rechtsgeschichte, R. A. 80, 1963.

MITTEIS, Ludwig. Die Lehre von der Stellvertretung nach römischem Recht mit Berücksichtigung des österreichischen Rechts. Wien: Alfred Hölder, 1885. 
MITTEIS, Ludwig. Reichsrecht und Volksrecht in den östlichen Provinzen des römischen Kaiserreichs. Leipzig: B. G. Teubner, 1891.

MITTEIS, Ludwig. Römisches Privatrecht bis auf die Zeit Diokletians. Leipzig: Duncker \& Humblot, 1908.

MOMIGLIANO, Arnaldo. Le conseguenze del rinnovamento della storia dei diritti antichi. Rivista Storica Italiana, n. 76, p. 133-149, 1964.

MOMIGLIANO, Arnaldo; SCHIAVONE, Aldo (dir.). Storia di Roma. Torino: Einaudi, 1990.

MOMMSEN, Theodor. Römisches Strafrecht. Leipzig: Duncker \& Humblot, 1899.

MONATERI, Pier Giuseppe. Black Gaius: A Quest for the Multicultural Origins of the 'Western Legal Tradition'. Hastings Law Journal, v. 51, n. 3, p. 479-564, 2000.

MONATERI, Pier Giuseppe. Gayo, el Negro: una búsqueda de los orígenes multiculturales de la tradición jurídica occidental. In: MONATERI, P. G.; SAMUEL, Geoffrey. La invención del Derecho privado. Bogotá: Siglo del Hombre Editores, 2006.

MORENO CUÑAT, María José. Algunas consideraciones acerca del idealismo neohegeliano en Italia. Anuario de la Facultad de Derecho Universidad de Extremadura (AFDUE), v. 5, p. 545-556, 1987.

MORGAN, Lewis H. Ancient Society. New York: Holt, 1877.

MURGA GENER, José Luis. El edificio como unidad en la jurisprudencia romana y en la lex. Sevilla: Servicio de Publicaciones de la Universidad, 1986.

MURGA GENER, José Luis. Protección a la estética en la legislación urbanística del Alto Imperio. Sevilla: Publicaciones de la Universidad, 1976.

MURGA GENER, José Luis; PARICIO, Javier. La denuncia de obra nueva en el Derecho Romano clásico. Barcelona: Bosch, 1982.

NOIRIEL, Gérard. Sobre la crisis de la historia. Madrid: Cátedra, 1997.

NÖRR, Dieter. Imperium und Polis in der Hohen Prinzipatszeit. München: Beck, 1969.

NÚÑEZ PAZ, María Isabel. Derecho romano, Derecho común y contratación en el marco de la Unión Europea. Oviedo: Universidad de Oviedo, 2000.

ORESTANO, Riccardo. Diritto, incontri e scontri. Bologna: Il Mulino, 1981.

ORESTANO, Riccardo. Il diritto romano nella scienza del diritto. Jus, ano II, fasc. II, Milano, Università Cattolica del Sacro Cuore, p. 141-178, esp. p. 144, 1951.

ORESTANO, Riccardo. Introduzione allo studio del diritto romano. Bologna: Il Mulino, 1987. 
PARICIO, Javier. Contrato. Formación de un concepto. Cizur Menor: Thompson-Civitas, 2008.

PARICIO, Javier. El legado jurídico de Roma. Madrid: Marcial Pons, 2010.

PARICIO, Javier. Historia y Fuentes del Derecho Romano. Madrid: Centro de Estudios Ramón Areces, 1988.

PÉREZ-PRENDES, José Manuel. Las bienaventuranzas del Derecho romano. Madrid: Iustel, 2010.

PETIT CALVO, Carlos. El romano de Pompeyo o hic sunt leones. Anuario de Historia del Derecho Español, n. 69, p. 563-606, 1990.

PETIT, Paul. Historia de la Antigüedad. Barcelona: Labor, 1967.

PIGANIOL, André. Historia de Roma. Buenos Aires: EUDEBA, 1961.

PINA POLO, Francisco. Las contiones civiles y militares en Roma. Zaragoza: Universidad de Zaragoza, 1989.

PINA POLO, Francisco; MARCO SIMÓN, Francisco; REMESAL RODRÍGUEZ, José (coord.). Repúblicas y ciudadanos, modelos de participación cívica en el mundo antiguo. Barcelona: Universidad de Barcelona, 2006.

PUGLIESE, G. Il diritto romano nella formazione del giurista, oggi. Convegno organizzato dalla Facoltà di giurisprudenza della II Università di Roma. Milano: Giuffrè, 1989.

RABEL, Ernst. El fomento internacional del Derecho privado. Revista de Derecho privado, $\mathrm{n}$. 18,1931, p. 42 et seq.

RAMPAZZO, Natale. Quasi prator non fuerit. Studi sulle elezioni magistratuali in Roma repubblicana tra regola ed eccezione. Napoli: Satura Editrice, 2008.

RASCÓN GARCÍA, César. Síntesis de historia e instituciones de Derecho romano. Madrid: Tecnos, 2006.

RIBAS ALBA, José María. Democracia en Roma. Introducción al Derecho electoral romano. Granada: Comares, 2008.

RIBAS ALBA, José María. Libertad. La vía romana hacia la democracia. Granada: Comares, 2009.

RICCOBONO, Salvatore. Lineamenti della Storia delle Fonti e del Diritto Romano. Compendio del Corsi di Storia e d'esegesi del Diritto Romano. Milano: Giuffrè, 1949.

ROBERTIS, Francesco Maria de. Lavoro e lavoratori nel mondo romano. Bari: Adriatica, 1963. 
RODRÍGUEZ MONTERO, Ramón P. Usos sociales y regulación jurídica de la capacidad patrimonial de los 'filii familias': puntos de referencia del desarrollo estructural y funcional del 'peculium a patre profectum, castrense' y 'quasi castrense' en Roma. Anuario da Facultade de Dereito da Universidade da Coruña, n. 2, p. 419-430, 1998.

ROLDÁN HERVÁS, José Manuel. El orden constitucional romano en la primera mitad del siglo II a.C.: de la res publica aristocrática a la res publica oligárquica. Gerión-Revista de Historia Antigua, n. 2, p. 67-100, 1984.

ROSTOVTZEFF, M. Historia Social y Económica del Imperio Romano. Madrid: EspasaCalpe, 1972.

ROULAND, Norbert. Anthropologie juridique. Paris: PUF, 1988.

ROYO ARPÓN, José María. Ciudad abierta. Ciudad de Ciudadanos. Madrid: Marcial Pons, 2001.

ROYO ARPÓN, José María. Palabras con poder. Madrid: Marcial Pons, 1997.

RÜCKERT, Joachim. Savignys Einflu $\beta$ auf die Jurisprudenz in Deutschland nach 1900. In.: MOHNHAUPT, Heinz. Rechtsgeschichte in den beiden deutschen Staaten (1988-1990). Frankfurt am Main: Klostermann, 1991. p. 34-71.

SAINZ-EZQUERRA, José María. Apuntes actuales sobre metodología romanística clásica. Anales de la Facultad de Derecho de la Universidad de La Laguna, n. 9, p. 36-38, 19811982.

SANTALUCIA, Bernardo. Altri studi di diritto penale romano. Padova: CEDAM, 2009.

SCHIAVONE, Aldo. Alle origini del diritto borghese: Hegel contro Savigny. Roma; Bari: Laterza, 1984.

SCHIAVONE, Aldo. Ius. L'invenzione del diritto in Occidente. Torino: Einaudi, 2005.

SCHIAVONE, Aldo. Ius. La invención del Derecho en Occidente. Buenos Aires: Adriana Hidalgo, 2009.

SCHIAVONE, Aldo. La storia spezzata. Roma antica e Occidente moderno. Roma; Bari: Laterza; Fili Spa, 1999.

SCHIAVONE, Aldo. Storiografia e critica del diritto: per una 'archeologia' del diritto privato moderno. Bari: De Donato, 1880.

SCHIAVONE, Aldo. Storiografia giuridica e apologia del diritto moderno. Democrazia e Diritto, v. XIII, n. 2, p. 65-86, 1973.

SCHIPANI, Sandro (coord.). Diritto romano, rivoluzioni, codificazioni. Index, Quaderni Camerti di Studi Romanistici, n. 14, 1986. 
SCHULTZ, Fritz. Classical Roman Law. Oxford: Clarendon Press, 1951.

SCHULTZ, Fritz. Geschichte der römischen Rechtswissenschaft. Weimar: Böhlaus, 1961.

SCHULTZ, Fritz. History of Roman Legal Science. Oxford: Clarendon Press, 1946.

SCHULTZ, Fritz. Principios del Derecho Romano. Madrid: Universidad Complutense, 1990.

SLOOTJES, Daniëlle. The governor and his subjects in the Later Roman Empire. Leiden: Brill, 2006.

STEIN, Peter. El Derecho romano en la historia de Europa. Historia de una cultura jurídica. Madrid: Siglo XXI Editores, 2001.

STEIN, Peter. Roman law in European history. Cambridge: Cambridge University Press, 1999.

TALAMANCA, Mario (ed.). Lineamenti di storia del diritto romano. Milano: Giuffrè, 1979.

TORRENT, Armando. Derecho público romano y sistema de fuentes. Oviedo: Universidad de Oviedo, 1982.

TORRENT, Armando. Fundamentos del Derecho europeo. Ciencia del Derecho: Derecho romano - ius commune - Derecho europeo. Madrid: Edisofer, 2007.

TORRENT, Armando. Introducción metodológica al estudio del Derecho romano. Oviedo: Universidad de Oviedo, 1974.

VACCA, Letizia. La giurisprudenza nel sistema delle fonti del diritto romano. Torino: Giappichelli, 1989.

VILAJOSANA, Josep M. El significado político del Derecho. México: Fontamara, 1997.

WATSON, Alan. Legal History and a Common Law for Europe: Mystery, Reality, Imagination. Stockholm: Olin Foundation for Legal History, 2001.

WATSON, Alan. The Spirit of Roman Law. Athens: University of Georgia Press, 1995.

WENGER, Leopold. Der heutige Stand der römischen Rechtswissenschaft. München: Beck, 1927.

WENGER, Leopold. Römische und antike Rechtsgeschichte. Graz: Leuschner \& Lubensky's Universitäts-Buchhandlung, 1905.

WHITMAN, James Q. The legacy of Roman law in the German romantic era: historical vision and legal change. Princeton: Princeton University Press, 1990. 
WIEACKER, Franz. A History of Private Law in Europe, With Particular Reference to Germany. Oxford: Clarendon Press, 1995.

WIEACKER, Franz. Privatrechtsgeschichte der Neuzeit unter besonderer Berücksichtigung der deutschen Entwicklung. Göttingen: Vandenhoeck \& Ruprecht, 1967.

WIEACKER, Franz. Römische Rechtsgeschichte. 2 v. München: Beck, 1988 e 2006.

ZIMMERMANN, Reinhard. Derecho romano, Derecho contemporáneo, Derecho europeo: La tradición del Derecho civil en la actualidad. Bogotá: Universidad Externado de Colombia, 2010.

ZIMMERMANN, Reinhard. Europa y el Derecho romano. Estudio introductorio y traducción de I. Cremades Ugarte. Madrid: Marcial Pons, 2009.

ZIMMERMANN, Reinhard. Handwörterbuch des Europäischen Privatrechts. v. 1-2.

Tübingen: Mohr Siebeck, 2009.

ZIMMERMANN, Reinhard. Roman Law, Contemporary Law, European Law: The Civilian Tradition Today. Oxford: Oxford University Press, 2001.

ZIMMERMANN, Reinhard. Savignys Vermächtnis: Rechtsgeschichte, Rechtsvergleichung und die Begründung einer Europäischen Rechtswissenschaft. Tübingen: Juristische Blätter, 1998.

ZIMMERMANN, Reinhard. The Law of Obligations: Roman Foundations of the Civilian Tradition. Cape Town: Juta \& Co., 1990.

\section{DADOS DA PUBLICAÇÃO}

Categoria: artigo de autor convidado.

Recebido em: 12/02/2021.

Aceito em: 01/03/2021. 